\title{
Comparative water use in short-rotation Eucalyptus benthamii and Pinus taeda trees in the Southern United States
}

\author{
Chris A. Maier ${ }^{\mathrm{a}, *}$, Timothy J. Albaugh ${ }^{\mathrm{b}}$, Rachel I. Cook ${ }^{\mathrm{c}}$, Kevin Hall ${ }^{\mathrm{c}}$, Daniel McInnis ${ }^{\mathrm{d}}$, Kurt H. Johnsen ${ }^{\mathrm{e}}$, \\ John Johnson ${ }^{\mathrm{f}}$, Rafael A. Rubilar ${ }^{\mathrm{g}}$, James M. Vose ${ }^{\mathrm{h}}$ \\ ${ }^{a}$ US Forest Service, Southern Research Station, 3041 Cornwallis Road, Research Triangle Park, NC 27709, USA \\ ${ }^{\mathrm{b}}$ Virginia Tech Department of Forest Resources and Environmental Conservation, 228 Cheatham Hall, Blacksburg, VA 24061, USA \\ ${ }^{\mathrm{c}}$ Department of Forestry and Environmental Resources, Box 8008, North Carolina State University, Raleigh, NC 27695-8008, USA \\ ${ }^{\mathrm{d}}$ US Forest Service, Southern Region, 1720 Peachtree Road, NW, Atlanta, GA 30309, USA \\ ${ }^{\mathrm{e}}$ US Forest Service, Southern Research Station, 1577 Brevard Road, Asheville, NC 28806, USA \\ f 1004 Crooked Oak Rd, Summerville, SC 29485, USA \\ ${ }^{\mathrm{g}}$ Departamento de Silvicultura, Facultad de Ciencias Forestales, Universidad de Concepción, Concepción, Chile \\ ${ }^{\mathrm{h}}$ US Forest Service, Southern Research Station, Raleigh, NC 27695, USA
}

\section{A R T I C L E I N F O}

\section{Article history:}

Received 30 September 2016

Received in revised form 24 April 2017

Accepted 26 April 2017

Available online 4 May 2017

\section{Keywords:}

Sap flow

Thermal dissipation probes

Transpiration

Canopy conductance

Water use efficiency

Loblolly pine

\begin{abstract}
A B S T R A C T
Short rotation Eucalyptus plantations offer great potential for increasing wood-fiber production in the southern United States. Eucalyptus plantations can be highly productive ( $>35 \mathrm{~m}^{3} \mathrm{ha}^{-1}$ year $\left.^{-1}\right)$, but they may use more water than intensively managed pine (primarily Pinus taeda L.) plantations. This has raised concern about how expansion of Eucalyptus plantations will affect water resources. We compared tree water use, stem growth, and WUE ( $\mathrm{kg}$ wood per $\mathrm{m}^{3}$ water transpired) in adjacent nine-year-old Eucalyptus benthamii and P. taeda plantations with similar stand density and leaf area. Sap flux $\left(F_{\mathrm{d}}\right.$, $\mathrm{g} \mathrm{cm}^{-2} \mathrm{~s}^{-1}$ ) was measured continuously over one year using thermal dissipation probes. Stem biomass, stem growth, tree water use $\left(E_{\mathrm{t},} \mathrm{L} \mathrm{day}^{-1}\right)$, canopy transpiration per unit leaf area $\left(E_{\mathrm{l}}, \mathrm{mmol} \mathrm{m} \mathrm{m}^{-2} \mathrm{~s}^{-1}\right)$, and canopy stomatal conductance $\left(G_{\mathrm{s}}, \mathrm{mmol} \mathrm{m}^{-2} \mathrm{~s}^{-1}\right)$ were quantified. Eucalyptus had higher daily $F_{\mathrm{d}}$ $\left(196.6 \mathrm{~g} \mathrm{~cm}^{-2}\right.$ day $\left.^{-1}\right)$ and mean daily $E_{\mathrm{t}}\left(24.6 \mathrm{~L} \mathrm{day}^{-1}\right)$ than pine $\left(105.8 \mathrm{~g} \mathrm{~cm}^{-2}\right.$ day $\left.^{-1}, 15.2 \mathrm{~L} \mathrm{day}^{-1}\right)$. Eucalyptus exhibited a seasonally bimodal pattern in daily $E_{\mathrm{t}}$ that did not occur in pine. Monthly $E_{\mathrm{t}}$ was 23-51\% higher in Eucalyptus and differences between species were greatest in the spring and fall. Annual $E_{\mathrm{t}}$ was $32 \%$ higher in Eucalyptus $\left(9.13 \mathrm{~m}^{3} \mathrm{H}_{2} \mathrm{O}\right.$ year $\left.{ }^{-1}\right)$ than pine $\left(5.79 \mathrm{~m}^{3} \mathrm{H}_{2} \mathrm{O}\right.$ year $\left.{ }^{-1}\right)$. Annual stem biomass increment was greater in Eucalyptus (Eucalyptus: 22.9; pine: $11.8 \mathrm{~kg}^{-1} \mathrm{tre}^{-1} \mathrm{year}^{-1}$ ), and

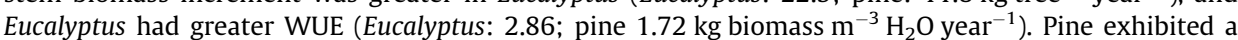
lower seasonal minimum and higher seasonal maximum leaf area index (LAI). At low LAI, there was no significant difference between species in $E_{1}$ or $G_{s}$; however, at maximum LAI, pine $E_{1}$ and $G_{\mathrm{s}}$ were 46 and $43 \%$, respectively of rates observed in Eucalyptus. The species differed in $G_{s}$ response to vapor pressure deficit $(D)$. At a similar reference $G_{\mathrm{s}}\left(G_{\mathrm{s}, \mathrm{ref}}\right.$ at $\left.D=1 \mathrm{kPa}\right)$, pine exhibited greater stomatal sensitivity to $D$. These results suggest that (1) Eucalyptus trees had higher sap flux and total water use than pine, (2) Eucalyptus had greater stem growth and WUE, and (3) species differences in water use were driven primarily by differences in $E_{1}$ and $G_{s}$.
\end{abstract}

Published by Elsevier B.V.

\section{Introduction}

In the Southern US, plantation forests are dominated by loblolly (Pinus taeda L.) and slash (P. elliottii Engalm) pine (16 million ha,

\footnotetext{
* Corresponding author.

E-mail addresses: cmaier@fs.fed.us (C.A._Maier), tim_albaugh@vt.edu (T.J. Albaugh),rlcook@ncsu.edu (R.I. Cook), kbhall2@ncsu.edu (K. Hall), dmcinnis@ fs.fed.us (D. McInnis), kjohnsen@fs.fed.us (K.H. Johnsen), 1004jjohnson@gmail.com (J. Johnson), rafaelrubilar@udec.cl (R.A. Rubilar), jvose@fs.fed.us (J.M. Vose).
}

Fox et al., 2007). Loblolly pine plantation silviculture, genetics, and forest operations are highly advanced making it a prime candidate for commercial bioenergy feedstock production (Kline and Coleman, 2010). However, frost tolerant, fast-growing Eucalyptus species are now being considered as an alternative short-rotation plantation species for pulp and feedstocks for bioenergy and bioproducts (Hinchee et al., 2009; Gonzalez et al., 2011; Dougherty and Wright, 2012,) and could potentially replace pine on some sites (Stanturf et al., 2013) particularly at lower latitudes. 
Eucalyptus plantations can be highly productive $\left(>35 \mathrm{~m}^{3} \mathrm{ha}^{-1}\right.$ year $^{-1}$ ) (Albaugh et al., 2013) compared to conventionally grown pine (25-27 $\mathrm{m}^{3} \mathrm{ha}^{-1} \mathrm{yr}^{-1}$ ) (Fox et al., 2007). Eucalypts have other advantages including short rotation length (6-8 years), potential for planting on marginal lands, ability to coppice producing multiple crops from a single planting, high wood bulk density, and excellent wood and fiber properties (Dougherty and Wright, 2012). Susceptibility to cold damage has limited commercial production of Eucalyptus in the Southern US (Vance et al., 2014). However, identification of frost tolerant species and hybrids along with improved silviculture protocols may make it possible to grow commercially viable plantations in USDA Plant Hardiness Zones $8 \mathrm{~b}$ and higher (annual minimum temperature $>9.4{ }^{\circ} \mathrm{C}$ (USDA, 2012). For example, Eucalyptus benthamii has shown superior growth (Hall, 2015) and can tolerate temperatures to $-12^{\circ} \mathrm{C}$ (Johnsen, personal communication) making this species suitable for much of the Gulf and Atlantic Coastal Plains in the Southern US.

The potential for widespread cultivation of Eucalyptus in the Southern US has presented several environmental considerations including unknown impact on biodiversity, susceptibility to fire, invasiveness (Callaham et al., 2013; Lorentz and Minogue, 2015), and water use (Stanturf et al., 2013). Eucalyptus culture is often linked to high water use relative to other species (Scott, 2005; Hubbard et al., 2010; Albaugh et al., 2013) and is controversial in some parts of the world because they often use more water than the vegetation they replace (Farley et al., 2005; Ferraz et al., 2013) and can reduce off-site water yield (Calder, 2002). Productivity and water use are tightly coupled and morphological and physiological traits such as high stomatal conductance, drought tolerance, evergreen leaves, and deep rooting (Whitehead and Beadle, 2004) contribute to Eucalyptus plantations having some of the highest evapotranspiration rates of tree species (Dye, 2013; Farley et al., 2005; Hubbard et al., 2010). Potential high water use and rapid growth coupled with the region's high potential evapotranspiration (PET) have important implications for the sustainable short-rotation production of Eucalyptus in the Southern US (Vose et al., 2015).

Intensively managed forest plantations generally use more water than less intensively managed or native forests (Cannell, 1999; Jackson et al., 2005); however, it is unknown if Eucalyptus plantations will use more water than intensively managed pine (P. taeda, P. elliotii) grown in the Southern US. Studies comparing water use between Eucalyptus and other species are rare (although see Benyon and Doody, 2015). Farley et al. (2005) showed that converting grasslands to Eucalyptus plantations reduced runoff 25\% more than converting grassland to pine indicating a higher rate of water use in Eucalyptus. Myers et al. (1996) found after several years of irrigation, that 3-year-old E. grandis plantations had $42 \%$ greater standing volume and use $22 \%$ more water than $P$. radiata. Similarly, in France, Moreaux et al. (2012) found that hybrid Eucalyptus (E. gunni x dalrympleana) plantations had 25\% higher evapotranspiration compared to native maritime pine ( $P$. pinaster), but Eucalyptus had $1.6 \times$ greater water use efficiency (WUE: biomass growth per unit water transpired). In both of the above studies, the authors concluded that species differences in water use were a function of growth rate and stage of stand development and not to inherent differences in species physiology. Water use efficiency relates productivity and water consumption and is a useful metric to compare species water use and understand the relationship between water use, stand growth, and development. Eucalyptus plantations generally have high WUE (Stape et al., 2004) and fast growing Eucalyptus trees are thought to use water more efficiently than slower growing trees (Otto et al., 2014); however, it is unknown if Eucalyptus has greater WUE than pine, but evidence from overseas studies suggest a higher WUE for Eucalyptus (White et al., 2009). Understanding the physical and biological factors that regulate water use and quantifying species differences in water use and WUE are important for evaluating the hydrological behavior of short-rotation forest systems and implications for water resources.

Water consumption of short-rotation Eucalyptus plantations needs to be quantified in order to develop management and silvicultural practices that maximize productivity and WUE without compromising water resources and for evaluating the impact on water resources of replacing pine with Eucalyptus. Our objective was to compare tree water use and WUE over one year in adjacent nine-year-old stands of $E$. benthamii and $P$. taeda plantations growing in the Coastal Plain of South Carolina. We hypothesized that Eucalyptus would have higher sap flux and tree water use, but because of greater growth and efficient stomatal regulation, Eucalyptus trees would have greater WUE.

\section{Methods}

\subsection{Study site}

The study site was located near Ravenel, SC $\left(32^{\circ} 45^{\prime} \mathrm{N} 80^{\circ} 14^{\prime} \mathrm{W}\right)$. The climate is warm and humid. Average January and July temperatures are 8.0 and $27.3^{\circ} \mathrm{C}$, respectively (1981-2010; NOAA Climate Data for Charleston, SC). Annual rainfall is $1345 \mathrm{~mm}$ with $37 \%$ of this occurring during summer (June-August). Potential evapotranspiration (PET) generally is less than annual precipitation, although extended droughts during the growing season are common. The soils are a fine-loamy, mixed, active, thermic Typic Endoaqualfs (Yonges series) and are poorly drained with a high water table. Tree sap flux and growth were measured in adjacent stands of nine-year-old $E$. benthamii and $P$. taeda. Stands were separated by a $10 \mathrm{~m}$ wide access road. The $E$. benthamii stand was a provenance test planted in 2004. Seedlings were flat planted at $3 \times 3 \mathrm{~m}$ spacing $\left(1080\right.$ trees ha $\left.^{-1}\right)$. The Eucalyptus stand was devoid of understory vegetation. The pine stand was planted with mass control pollinated seedlings on beds at $1.8 \times 4.3 \mathrm{~m}$ spacing $\left(1280\right.$ trees ha $\left.^{-1}\right)$. The understory in the pine was mechanically removed in a $650 \mathrm{~m}^{2}$ area (84 trees) prior to the experiment. Regrowth of the understory was minimal during the study. Twelve trees of each species with diameters within one standard deviation of the stand mean with no missing adjacent trees were selected for sap flux measurement (Table 1). Plot areas were 108 and $94 \mathrm{~m}^{2}$ for the Eucalyptus and pine, respectively.

\subsection{Environmental monitoring}

Air temperature, relative humidity (Vaisala HMP-60, Campbell Scientific, Logan, Utah), photosynthetically active radiation (PAR) (LI-190s, Licor, Lincoln, NE, USA), and precipitation were measured in an open field adjacent to the study site. Precipitation and PAR were also measured in the understory. Vapor pressure deficit $(D$, $\mathrm{kPa}$ ) was calculated from relative humidity and air temperature (Jones, 1986). Soil volumetric water content (VCW, $\mathrm{m}^{3} \mathrm{~m}^{-3}$ ) was measured continuously at one location in each plot using a multiple annular capacitance sensor (Sentek PTY LTD, Adelaide, Australia) placed at $30 \mathrm{~cm}$.

\subsection{Biometric measurements and tree biomass}

Stem diameter $(\mathrm{cm})$ at $1.3 \mathrm{~m}(\mathrm{dbh})$ was measured bimonthly or monthly. Daily changes in diameter were estimated by interpolation and were used to estimate sapwood area $\left(A_{s}\right)$. Sapwood thickness in E. benthamii was measured visually from a clearly defined color change at the boundary between sapwood and heartwood $(2.99 \pm 27 \mathrm{~cm}, \mathrm{n}=10)$. Sapwood area was derived from over bark diameter using an exponential expression, where $A_{\mathrm{S}}\left(\mathrm{cm}^{2}\right)$ 
Table 1

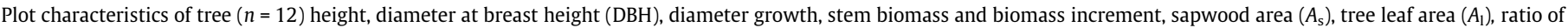

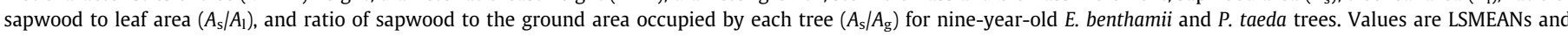
standard error (SE). Plot-level leaf area index $\left(\mathrm{LAI}_{\mathrm{p}}\right)$, tree density, and basal area (BA) are also given.

\begin{tabular}{|c|c|c|c|c|}
\hline Variable & E. benthamii ${ }^{1}$ & P.taeda & SE & P-value \\
\hline Height (m) & $19.0^{\mathrm{a}}$ & $13.3^{\mathrm{b}}$ & 0.9 & 0.001 \\
\hline $\mathrm{DBH}(\mathrm{cm})$ & $16.6^{\mathrm{a}}$ & $14.5^{\mathrm{a}}$ & 0.9 & 0.126 \\
\hline Diameter growth $\left(\mathrm{cm}^{2}\right)$ & $1.79^{\mathrm{a}}$ & $1.68^{\mathrm{a}}$ & 0.18 & 0.644 \\
\hline Stem biomass ( $\mathrm{kg} \mathrm{tree}^{-1}$ ) & $114.9^{\mathrm{a}}$ & $44.7^{\mathrm{b}}$ & 10.8 & $<0.001$ \\
\hline Stem increment ( $\mathrm{kg}$ tree $\mathrm{e}^{-1} \mathrm{yr}^{-1}$ ) & $22.9^{\mathrm{a}}$ & $11.8^{\mathrm{b}}$ & 2.9 & 0.013 \\
\hline$A_{\mathrm{s}}\left(\mathrm{cm}^{2}\right)$ & $113.0^{\mathrm{a}}$ & $125.6^{\mathrm{a}}$ & 10.6 & 0.421 \\
\hline$A_{1}\left(\mathrm{~m}^{2}\right)^{2}$ & $24.3^{\mathrm{a}}$ & $39.7^{\mathrm{a}}$ & 4.0 & 0.020 \\
\hline$A_{\mathrm{s}} / A_{\mathrm{l}}\left(\mathrm{cm}^{2} \mathrm{~m}^{-2}\right)$ & $5.74^{\mathrm{a}}$ & $3.18^{\mathrm{b}}$ & 0.42 & 0.001 \\
\hline$A_{\mathrm{s}} / A_{\mathrm{g}}\left(\mathrm{cm}^{2} \mathrm{~m}^{-2}\right)$ & $13.3^{\mathrm{a}}$ & $16.1^{\mathrm{b}}$ & 0.4 & $<0.001$ \\
\hline $\mathrm{LAI}_{\mathrm{p}}$ (February) & 2.40 & 2.03 & $N A^{3}$ & $N A$ \\
\hline LAI $_{p}$ (September) & 2.92 & 3.71 & $N A$ & $N A$ \\
\hline Density (trees ha ${ }^{-1}$ ) & 1084 & 1280 & $N A$ & $N A$ \\
\hline $\mathrm{BA}\left(\mathrm{m}^{2} \mathrm{ha}^{-1}\right)$ & 24.9 & 21.6 & $N A$ & $N A$ \\
\hline
\end{tabular}

1 Superscript letters denote significant differences across rows at $\alpha=0.05$.

2 Tree leaf area for pine is total (all-sided) leaf area.

3 Not applicable.

$=-33.245+6.087 *$ diameter $^{1.129}\left(R^{2}=0.91\right)$. In $P$. taeda, all of the xylem was considered hydro-active as heartwood does not develop until 15-20 years (Schultz, 1997).

Continuous measurement of stem diameter was made using custom-made automated dendrometer bands. Bands consisted of a metal tape, spring, and a potentiometer (Robert Teskey, personal communication). Bands were installed in mid-April on all of the trees. However, because of equipment failure or inconsistent signals from the potentiometers only nine Eucalyptus and ten pine trees provided useful data. Therefore, data from the automated bands are used only to describe seasonal patterns of stem growth.

Stem and foliage biomass was estimated from stand-specific allometric equations. Equations for Eucalyptus are given in Hall (2015). For the pine, six trees were harvested at the end of the study and partitioned into stem, foliage and branches. Stem biomass was estimated as $\ln ($ stem biomass $)=-1.8606+2.1065 * \ln$ $(\mathrm{dbh})\left(R^{2}=0.93, \mathrm{MSE}=0.1040, P=0.002\right)$ and tree foliage biomass as $\ln$ (foliage biomass $)=-7.5544+3.2364 * \ln (\mathrm{dbh}) \quad\left(R^{2}=0.98\right.$, MSE $=0.0799, P<0.001)$. Annual stem biomass increment was estimated as the difference between biomass at the beginning and end of the study.

Plot-level leaf area index ( $\mathrm{LAI}_{\mathrm{P}}$ ) was measured in February and September using a LAI-2000 Plant Canopy Analyzer (Licor Inc, Lincoln, NE, USA) (Table 1). These months correspond to the annual minimum and maximum LAI for P. taeda (Albaugh et al., 1998). The seasonal pattern of pine $\mathrm{LAI}_{\mathrm{P}}$ was simulated following Sampson et al. (2003) (Fig. 1). No LAIP data were available for $E$. benthamii in the Southern US. However, in the southern hemisphere, the LAI of Eucalyptus sp. plantations under non-limiting soil moisture are typically at an annual minimum in early spring and maximum in late summer (Whitehead and Beadle, 2004). We assumed that Eucalyptus LAI $_{\mathrm{p}}$ in February and September measurements represented the seasonal minimum and maximum and a linear increase in $\mathrm{LAI}_{\mathrm{p}}$ (White et al., 1998) from March through September. Tree-level leaf area index $\left(\mathrm{LAI}_{\mathrm{T}}\right)$ was estimated as the quotient of tree leaf area and the ground area occupied by each tree in the plot. Ground area for each tree $\left(A_{\mathrm{g}}\right)$ was the proportion of plot area occupied by each tree adjusted for tree size (i.e. tree cross sectional stem area at DBH divided by the plot area: Euclayptus: $108 \mathrm{~m}^{2}$; pine: $94 \mathrm{~m}^{2}$ ). Tree leaf area in February was determined from tree foliage biomass and specific leaf area (pine: $50 \mathrm{~cm}^{2} \mathrm{~g}^{-1}$, Vose and Allen, 1988). As no specific leaf area data was available for mature $E$. benthamii, we assumed a value of 60 $\mathrm{cm}^{2} \mathrm{~g}^{-1}$ typical for plantation Eucalytus $s p$ (Whitehead and Beadle, 2004). Mean tree $\mathrm{LAI}_{\mathrm{T}}$ in February was $2.48 \pm 0.15 \mathrm{SE}$ and

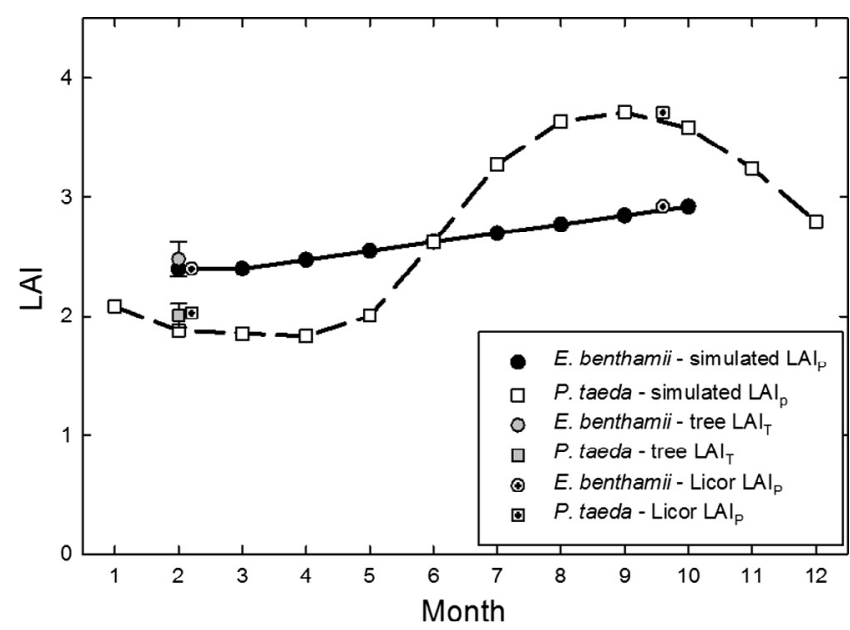

Fig. 1. Monthly simulated plot leaf area index $\left(\operatorname{LAI}_{P}\right)$ compared to measured $\operatorname{LAI}_{P}$ and estimated individual tree LAI $\left(\mathrm{LAI}_{\mathrm{T}}\right)$.

$2.01 \pm 0.08$ SE for Eucalytpus and pine, respectively, which compared well to the measured $\mathrm{LAI}_{\mathrm{P}}$ (Fig. 1). $\mathrm{LAI}_{\mathrm{T}}$ for other times of the year was adjusted based on the seasonal dynamics of $\mathrm{LAI}_{\mathrm{P}}$.

\subsection{Sap flux density measurements}

Sap flux density $\left(F_{\mathrm{d}}\right)$ was measured using custom-made $20 \mathrm{~mm}$ thermal dissipation probes (TDP) similar to Granier (1985). Each tree was instrumented using two probes per tree installed in the outer $20 \mathrm{~mm}$ of sapwood on an east and west azimuth between 1.2 and $1.6 \mathrm{~m}$ above the soil surface. Three or four trees in each stand had an additional $20 \mathrm{~mm}$ probe installed at the $20-40 \mathrm{~mm}$ depth perpendicular to the outer probes to measure the sap flux radial profile (Phillips et al., 1996). Outer TDPs were installed in January and inner probes installed in July and August. Probes were shielded from radiation heating using aluminum pans. Voltage signals from the probes were queried every $15 \mathrm{~s}$ and the $30 \mathrm{~min}$ average recorded using a data logger (CR-1000, Campbell Scientific). Sap flux density $\left(F_{\mathrm{d}}, \mathrm{g} \mathrm{m}^{-2} \mathrm{~s}^{-1}\right)$ was calculated using the standard equation (Granier, 1985):

$F_{\mathrm{d}}=119 *\left(\left(\Delta T_{\max }-\Delta T\right) / \Delta T\right)^{1.231}$,

where $\Delta T$ is the temperature difference between heated and unheated probe and $\Delta T_{\max }$ is the $\Delta T$ under no flow conditions 
$\left(F_{\mathrm{d}}=0\right)$ usually occurring at night. Eucalyptus and pine are known to have significant nocturnal $F_{\mathrm{d}}$ at high $D$ (Oren et al., 1999; Phillips et al., 2010). $\Delta T_{\max }$ was calculated using a program that accounted for the effects of nighttime $F_{\mathrm{d}}$ on the baseline signal (Baseliner, Duke University, Oishi et al., 2008). Conditions for zero nighttime flow were met when average $D<0.05 \mathrm{kPa}$ for at least two hours.

Sap flux density measured at 20-40 mm xylem depth was lower than in the outer xylem (0-20 mm), and the relationship between inner and outer xylem was linear (Fig. 2). In Eucalyptus, $F_{\mathrm{d}}$ at 20$40 \mathrm{~mm}$ was $0.09 * F_{\mathrm{d}}$ (i.e. average slope of all trees) of the outer 0-20 mm. Sapwood thickness was 30.3, 23.6, and $23.6 \mathrm{~mm}$ in trees 2,6 , and 9 , respectively indicating that $50-82 \%$ of the inner probe was in contact with non-conducting xylem, which can result in an underestimate of $F_{\mathrm{d}}$ (Clearwater et al., 1999). Inner xylem $F_{\mathrm{d}}$ corrected for the proportion of the probe in non-conducting xylem (Clearwater et al., 1999) was on average $0.16 * F_{\mathrm{d}}$ in the outer xylem. This ratio was use to estimate $F_{\mathrm{d}}$ for xylem $>20 \mathrm{~mm}$. In pine, $F_{\mathrm{d}}$ at $20-40 \mathrm{~mm}$ was $0.58 * F_{\mathrm{d}}$ of the outer sapwood similar to that reported by Phillips et al. (1996) for 12 year-old trees. To estimate $F_{\mathrm{d}}$ of deeper xylem ( $>40 \mathrm{~mm}$ ), a three parameter Gaussian function was used to calculate the radial distribution of $F_{\mathrm{d}}$ (Ford et al., 2004):

$F(x)=\alpha * \exp \left(\left(-0.5\left(\left(x-x_{0}\right) / \beta\right)^{2}\right)\right.$

where $x$ is xylem depth from the cambium, $\alpha$ is maximum $F_{\mathrm{d}}$, and $x_{\mathrm{o}}$ is depth of maximum $F_{\mathrm{d}}$ (in this case, $0-20 \mathrm{~mm}$ ). The $\beta$ parameter describes the radial profile and is inversely related to the rate of decrease in $F_{\mathrm{d}}$ with depth and was estimated from the ratio of $F_{\mathrm{d}}$ $(20-40 \mathrm{~mm}) / F_{\mathrm{d}}(0-20 \mathrm{~mm})$. An average $F_{\mathrm{d}}$ was computed as the sum of $F_{\mathrm{d}}$ for each $20 \mathrm{~cm}$ segment weighted by the relative proportion of total sapwood at that depth (Hatton et al., 1990).

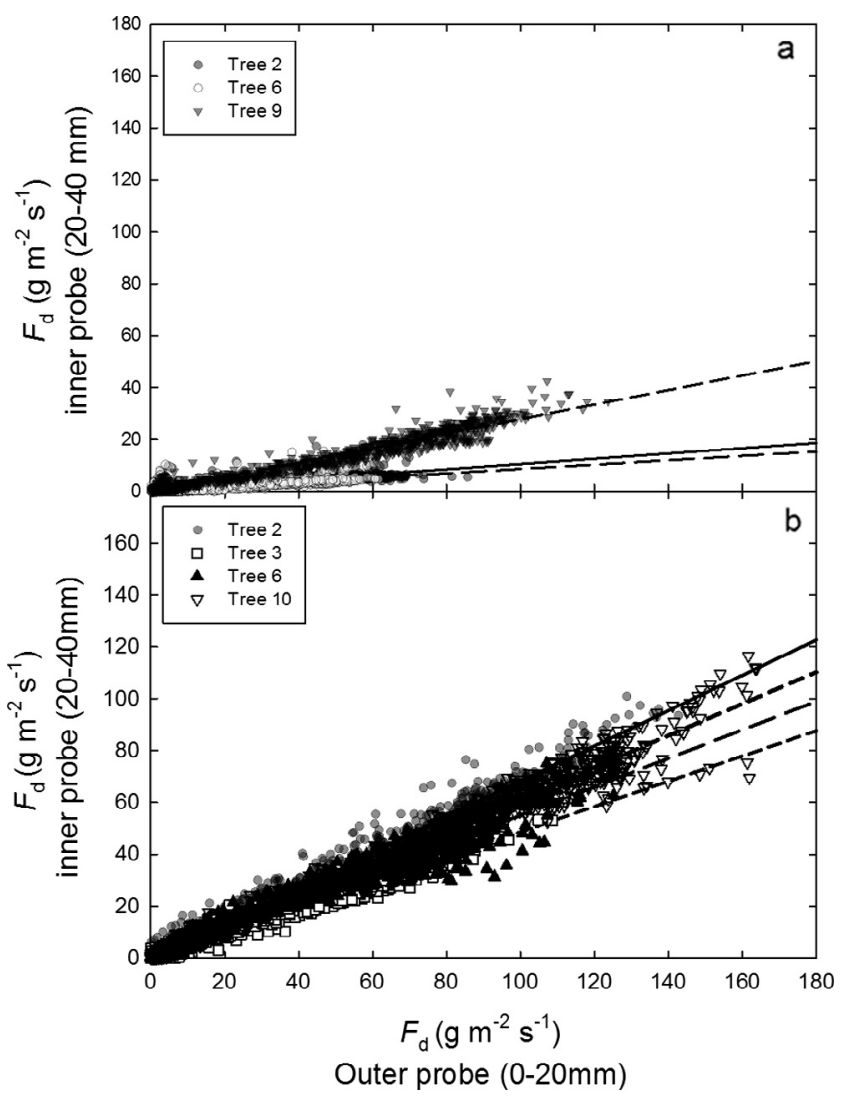

Fig. 2. The relationship between $F_{\mathrm{d}}$ in the inner $(20-40 \mathrm{~mm})$ and the outer $(0-$ $20 \mathrm{~mm}$ ) xylem in Eucalyptus (a) and pine (b) measured between day of year 230 and 304. Each data point is the hourly average $F_{\mathrm{d}}$.

\subsection{Calculation of tree transpiration and canopy conductance}

Tree water use or transpiration $\left(E_{\mathrm{t}}\right)$ was calculated for each 30 min period as the product of $F_{\mathrm{d}}$ and $A_{\mathrm{s}}$ and summed to daily $\left(\right.$ L day $\left.^{-1}\right)$, monthly, or annual $\left(\mathrm{m}^{3} \mathrm{H}_{2} \mathrm{O}\right.$ month ${ }^{-1}$ or year $\left.{ }^{-1}\right) E_{\mathrm{t}}$. Similarly, tree transpiration on a ground area basis $\left(E_{\mathrm{t}, \mathrm{g}}, \mathrm{mm}^{-1 a y}{ }^{-1}\right)$ was calculated as the product of $F_{\mathrm{d}}$ and $A_{\mathrm{s}} / A_{\mathrm{g}}$, where $A_{\mathrm{g}}$ is the proportion of the plot area occupied by the tree (Section 2.4). There were two days of missing data from the pine stand and 17 days missing from the Eucalyptus stand that occurred between day of year (DOY) 208 and 224. Daily $E_{\mathrm{t}}$ for missing days was estimated for each tree using a quadratic equation and $D$ based on $E_{\mathrm{t}}$ measured five days before and after missing data. $D$ explained 88$94 \%$ of the variation in daily $E_{\mathrm{t}}$ for both species.

Transpiration per unit leaf area $\left(E_{1}, \mathrm{mmol} \mathrm{m}^{-2} \mathrm{~s}^{-1}\right)$ was estimated by dividing $E_{\mathrm{t}}$ by $\mathrm{LAI}_{\mathrm{T}}$. Canopy stomatal conductance $\left(G_{\mathrm{s}}\right.$, mmol m$~^{-2}$ leaf area $\mathrm{s}^{-1}$ ) was calculated from $E_{1}$ and $D$ as:

$G_{\mathrm{s}}=\left(\lambda * E_{1} * \gamma\right) /\left(\rho * \mathrm{c}_{\mathrm{p}} * D\right)$

where $\lambda$ is the latent heat of vaporization of water $\left(2465 \mathrm{~J} \mathrm{~g}^{-1}\right), \gamma$ is the psychometric constant $\left(65.5 \mathrm{~Pa} \mathrm{~K}^{-1}\right), \rho$ is the density of air $\left(1225 \mathrm{~g} \mathrm{~m}^{-3}\right), c_{\mathrm{p}}$ is the specific heat of air $\left(1.01 \mathrm{~J} \mathrm{~g}^{-1} \mathrm{~K}^{-1}\right)$. Eq. (3) assumes a high boundary layer conductance relative to $G_{s}$. We followed the approach of Oren et al. (1999) to analyze the sensitivity of $G_{s}$ to $D$. Hourly $G_{s}$ were fitted to the model:

$G_{\mathrm{s}}=G_{\mathrm{s}, \mathrm{ref}} *-m \ln D$

where $G_{\mathrm{s}, \text { ref }}$ is reference $G_{\mathrm{s}}$ at $D=1 \mathrm{kPa}$ and $-m$ is the slope or sensitivity to $D\left(-d G_{s} / d \ln D\right)$. Hourly diurnal values of $G_{\mathrm{s}}$ where PAR $>1200 \mu \mathrm{mol} \mathrm{m}^{-2} \mathrm{~s}^{-1}$ (Samuelson and Stokes, 2006) and $D>0.75 \mathrm{kPa}$ were used to minimize potential constraints on $G_{\mathrm{s}}$ (Ewers and Oren, 2000).

\subsection{Statistical analysis}

Analysis of variance was used to analyze species difference in stand characteristics (height, diameter, $A_{S}, \mathrm{LAI}_{\mathrm{T}}$, biomass, and growth increment), $E_{\mathrm{t}}$, and WUE. Variables were transformed as appropriate to meet the assumptions of normality. One pine tree gave inconsistent $F_{\mathrm{d}}$ measurements and was dropped from the analysis of water use. The linear model for the analysis was

$Y_{\mathrm{ij}}=\mu+S_{\mathrm{i}}+T_{\mathrm{j}(\mathrm{i})}+\varepsilon_{\mathrm{ij}}$

where $Y_{\mathrm{ij}}$ is the response of the $j$ th tree $(j=1, \ldots, 11$ or 12$)$ in the $i$ th species $(i=1,2), \mu$ is the population mean, $S_{\mathrm{i}}$ the effect of species, $T_{\mathrm{j}(\mathrm{i})}$ is the effect of tree nested within species, and $\varepsilon_{\mathrm{ij}}$ is the error term. Species and tree were considered fixed and random effects, respectively. Repeated measures were used to analyze time series data (PROC MIXED) using a first order autoregressive covariance structure. Species differences in stand attributes, $E_{\mathrm{t}}$, and WUE were determined with LSMEANs statement using Tukey's adjustment. There are important limitations to the experimental design and analyses. In Eq. (5), the individual tree was considered the experimental unit $(n=12)$; however, this is not true replication as the trees were spatially segregated into a single plot. The confounding of species and plot precluded testing for species differences, thus statistical test are subject to an inflated probability of a Type I error. However, we suggest that the confounding between species and plot is small as the plots were close in space, on the same soil type, had similar topography, and experience similar environmental conditions. Nevertheless, inferences apply only to these two plots and extrapolation to a larger population should be made with caution.

Non-linear relationships between $G_{\mathrm{s}}$ and D were analyzed using PROC NLIN. Species and season differences in regression coefficients for Eq. (4) and the proportionality of $-m$ to $G_{s, \text { ref }}$ were tested 
using full and reduced models (PROC MIXED) (Zarnoch, 2009). Contrast statements were used to test for species and season effects on parameter estimates. All analyses were done in SAS (version 9.4, SAS Institute, Cary, North Carolina).

\subsection{TDP calibration}

Several studies have shown that the standard equation (Eq. (1)) can under or overestimate sap flux (Steppe et al., 2010; Hultine et al., 2010; Bush et al., 2010; Sun et al., 2012). Lu et al. (2004) suggested that the original calibration should be used with caution as it could vary with tree species, wood anatomy and thermal properties, and with differences in probe design and construction. We compared potometric estimates of sap flux density $\left(F_{\mathrm{d}, \mathrm{p}}\right)$ to that estimated using the original calibration in large diameter (10$18 \mathrm{~cm} \mathrm{dbh}$ ) field grown trees. Whole trees were used as potometers (Roberts, 1977; Gutiérrez and Santiago, 2006; Uddling et al., 2009; Sun et al., 2012) under ambient field conditions. TDP calibrations were performed on three four-year-old $E$. benthamii, three nine-year-old, and two eleven-year-old $P$. taeda trees. Measurements were made on warm sunny days in June and July (one tree per day). On the afternoon prior to calibration, two TDP were inserted radially in the outer $20 \mathrm{~mm}$ of xylem on opposite sides of the tree in an east-west orientation and $50-150 \mathrm{~cm}$ above ground level. The Eucalyptus had shallow sapwood depth (25$32 \mathrm{~mm}$ ), so only the outer $20 \mathrm{~mm}$ of xylem was measured. The pine had much deeper sapwood, so two additional probes were inserted $10 \mathrm{~cm}$ above and perpendicular to the outer probes at $20-40 \mathrm{~mm}$ to measure changes in $F_{\mathrm{d}}$ with sapwood depth. The outer $20 \mathrm{~mm}$ probe covered $62-80 \%$ of sapwood in Eucalyptus and the outer and inner probes together covered $49-84 \%$ of the sapwood in pine. A sapwood area average of $F_{\mathrm{d}, \mathrm{g}}$ was calculated based on the sapwood depth where $F_{\mathrm{d}, \mathrm{g}}$ for xylem in Eucalyptus $>20 \mathrm{~mm}$ and in pine $>40 \mathrm{~mm}$ was estimated as described in Section 2.4. Trees were cut in the morning before sunrise when transpiration was low to minimize xylem embolism at the cut surface. In order to move the tree after cutting and to secure the stem during measurement, the trunks were strapped to the articulating arm of a soil excavator or backhoe. Tree stems were cut diagonally near ground level with a chainsaw and cut ends immediately submerged in a 19-L reservoir filled with water. The base of the stem and reservoir were covered with insulation to minimize evaporation. Volumetric water uptake was measured every $30 \mathrm{~min}$ for the next 5-8 h. Potometer sap flux density $\left(F_{\mathrm{d}, \mathrm{p}}, \mathrm{g} \mathrm{m}^{-2} \mathrm{~s}^{-1}\right)$ was calculated as the quotient of water uptake and sapwood area.

\section{Results}

\subsection{TDP calibration}

At mid-day (1100-1300 h), Eucalyptus used 3.5-4.6 L $30 \mathrm{~min}^{-1}$ compared to $0.25-3.0 \mathrm{~L} 30 \mathrm{~min}^{-1}$ for pine. Cumulative water uptake from 0800 to $1300 \mathrm{~h}$ ranged from 27.6 to $40.9 \mathrm{~L}^{-1} \mathrm{tree}^{-1}$ in Eucalyptus compared to 3.5 to $17.8 \mathrm{~L} \mathrm{tree}^{-1}$ in pine (Fig. 3a). Eucalyptus also had higher water use per unit sapwood area (Eucalyptus: $0.48 \pm 0.03$; pine: $0.09 \pm 0.02 \mathrm{~L} \mathrm{~cm}^{-2}$ five hours ${ }^{-1}$ ). In pine, potometer measurements were $87 \%$ of estimated sap flow using the standard equation; however, this difference was not significant $(t=0.48, n=5, P=0.649)$. Potometer measurements of water use in Eucalyptus was 2.6-fold greater than estimated with the standard equation $(t=-9.36, n=3, P<0.001)$. In pine, sap flux estimated with the Granier equation $\left(F_{\mathrm{d}, \mathrm{g}}\right)$ was linearly correlated with sap flux measured with the potometer $\left(F_{\mathrm{d}, \mathrm{p}}\right)\left(R^{2}=0.86\right)$ and the slope was not significantly different from $1(P>0.05)$ (Fig. 3b). In Eucalyptus, $F_{\mathrm{d}, \mathrm{g}}$ severely underestimated $F_{\mathrm{d}, \mathrm{p}}$. The nonlinear model
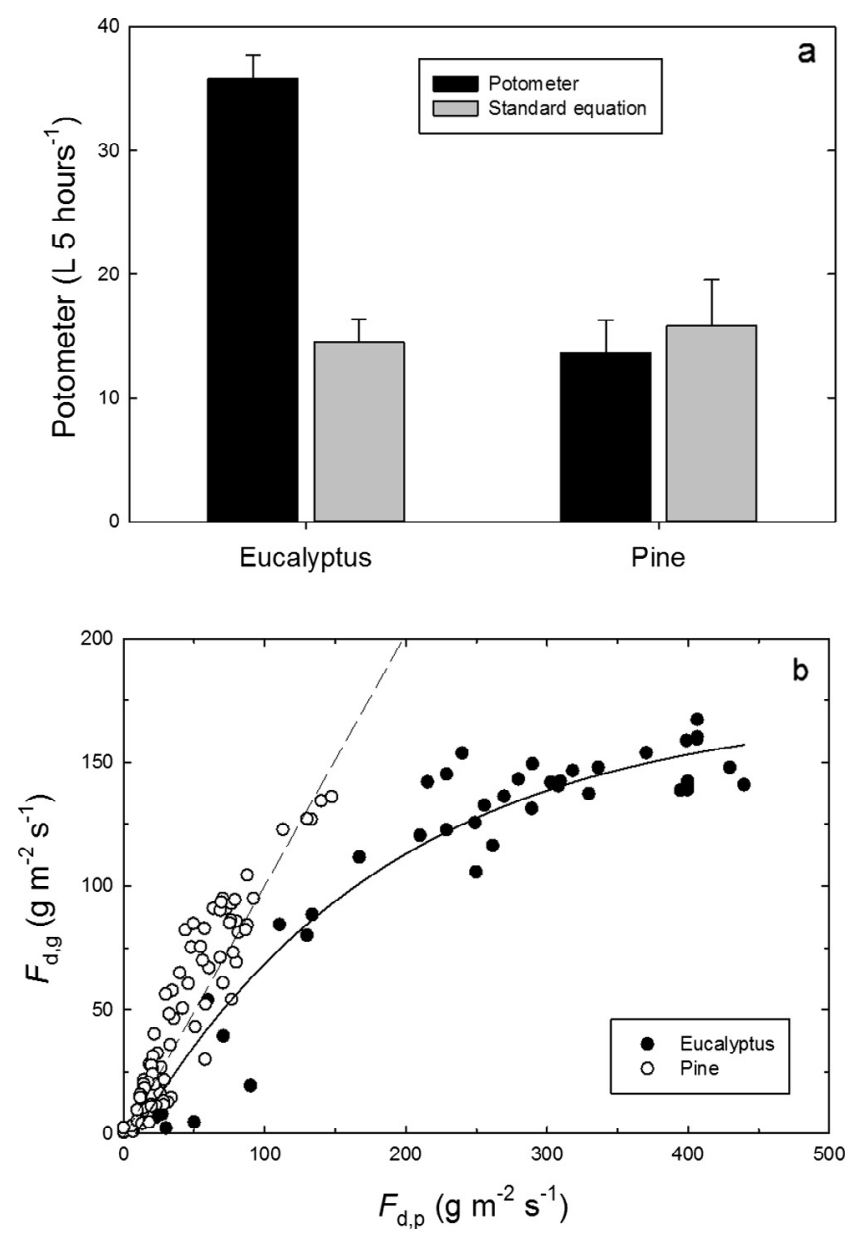

Fig. 3. (a) Mean cumulative water use over a five-hour period $(0800-1300 \mathrm{~h})$ measured with whole-tree potometers compared to estimated cumulative water uptake using the standard equation established by Granier $(1985)\left(F_{\mathrm{d}, \mathrm{g}}=119 x^{1.231}\right)$. Values are means \pm standard error for pine $(n=5)$ and Eucalyptus $(n=3)$. (b) Relationship between sap flux density estimated with standard equation $\left(F_{\mathrm{d}, \mathrm{g}}\right)$ and measured with the whole-tree potometer $\left(F_{\mathrm{d}, \mathrm{p}}\right)$. The solid line is the nonlinear regression of the form $y=157.8\left(1-e^{-0.0048 x}\right)\left(R^{2}=0.95\right)$. The dashed line is the $1: 1$ line.

$\left(y=a *\left(1-e^{-b x}\right)\right)$ resulted in the best fit $(\mathrm{a}=157.8 ; \mathrm{b}=0.0048$; $\left.R^{2}=0.95\right)$ between $F_{\mathrm{d}, \mathrm{g}}$ and $F_{\mathrm{d}, \mathrm{p}}$. This model was used to adjust $F_{\mathrm{d}}$ for Eucalyptus in the subsequent analyses.

\subsection{Environmental and stand characteristics}

Mean and maximum daily temperatures were typical of the 30year average; however, there were several freezing events between November 2013 and January 2014 where daily minimum temperatures fell below $-3{ }^{\circ} \mathrm{C}$ (Fig. 4a). Annual rainfall was $1630 \mathrm{~mm}, 19 \%$ greater than the 30 -year average $(1328 \mathrm{~mm})$ with $56 \%$ of the total occurring between June and August (DOY 153-244) (Fig. 4b). Daily mean vapor pressure deficit $(D)$ was low rarely exceeding $1 \mathrm{kPa}$, although maximum $D$ often exceeded $2.0 \mathrm{kPa}$ (Fig. 4c). There was high temporal variation in VWC (Fig. 4d). Volumetric water content at $30 \mathrm{~cm}$ ranged between 0.07 and 0.31 and was above 0.15 for much of the early to mid-growing season (DOY 60-240) except for a brief period in late May when VWC declined to close to 0.10. The seasonal pattern of VWC was similar between stands; however, VWC was more variable in Eucalyptus.

At the beginning of the study, Eucalyptus trees were significantly taller than pine and larger in diameter, although, diameter differences were not significant (Table 1). Ecualyptus stem biomass 


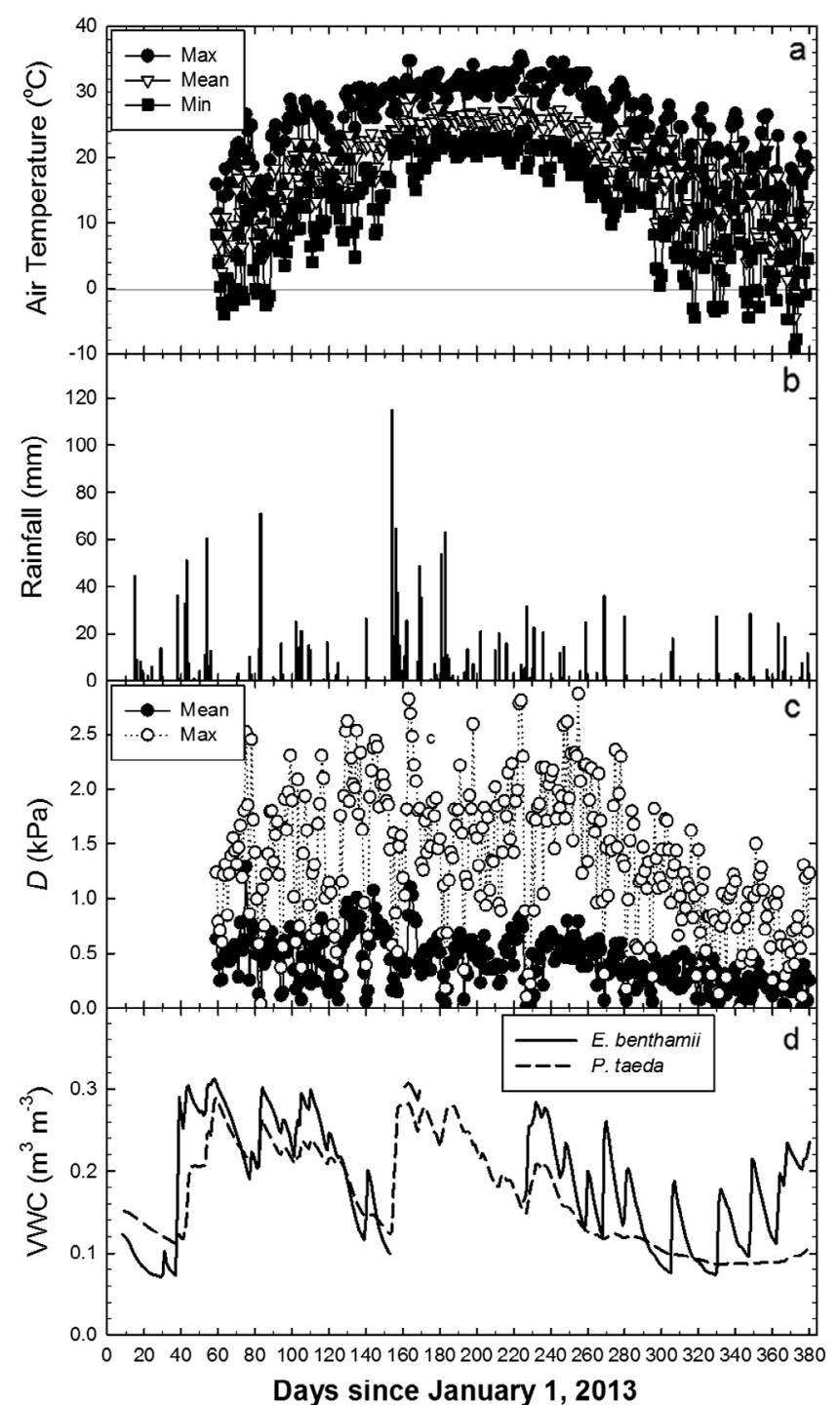

Fig. 4. (a) Daily minimum, mean, and maximum temperature, (b) daily precipitation, (c) mean and maximum air vapor pressure deficit $(D)$, and (d) daily averaged volumetric water content at a $30 \mathrm{~cm}$ soil depth.

was $114 \mathrm{~kg}$ tree ${ }^{-1}$ compared to $44.7 \mathrm{~kg}$ tree ${ }^{-1}$ in pine $(P<0.001)$. There was no difference in annual diameter increment; however, there was a difference in the seasonal pattern of diameter growth. Pine completed 95\% of annual diameter growth by early October (Fig. 5), whereas, in Eucalyptus, diameter growth was continuous throughout the year. Annual stem biomass increment was $22.9 \mathrm{~kg} \mathrm{tree}^{-1}$ for Eucalyptus compared to $11.8 \mathrm{~kg}^{-1} \mathrm{tree}^{-1}$ for pine $(P=0.013)$. Sapwood area was similar between species, however, Eucalyptus trees had significantly lower leaf area than pine and thus a significantly higher $A_{s}: A_{1}$ (Table 1 ). Pine exhibited a lower $\mathrm{LAI}_{\mathrm{p}}$ in February (2.03) and higher $\mathrm{LAI}_{\mathrm{p}}$ in September (3.71) than Eucalyptus (February: 2.40; September: 2.92).

\subsection{Tree sap flux $\left(F_{d}\right)$ and tree water use $\left(E_{t}\right)$}

Eucalyptus had a higher daily $F_{\mathrm{d}}$ than pine (Fig. 6a). Mean daily $F_{\mathrm{d}}$ was 196.6 and $105.8 \mathrm{~g} \mathrm{~cm}^{-2}$ day $^{-1}$ for Eucalyptus and pine, respectively $(\mathrm{SE}=2.4, P<0.001)$. The seasonal pattern of $F_{\mathrm{d}}$ differed with species. Both species reach a spring maximum around DOY 130150 (May-June) when $F_{\mathrm{d}}$ occasionally exceeded $400 \mathrm{~g} \mathrm{~cm}^{-2}$ day $^{-1}$ in Eucalyptus and $200 \mathrm{~g} \mathrm{~cm}^{-2}$ day $^{-1}$ in pine. Afterward, $F_{\mathrm{d}}$ gradually

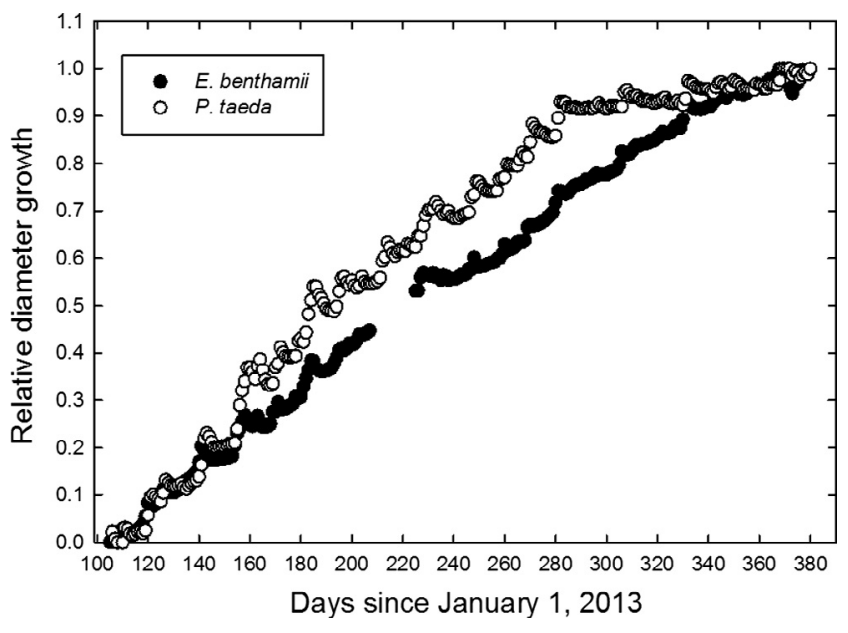

Fig. 5. Relative diameter growth of Eucalyptus and pine measured with automated dendrometer bands. Measurements began in mid-April. Each point represents the average of nine and six trees for Eucalyptus and pine, respectively.

declined in pine. In contrast, Eucalyptus exhibited a bimodal pattern where following the seasonal maximum, $F_{\mathrm{d}}$ declined during the summer, then increased again in late summer and fall. The largest species differences in $F_{\mathrm{d}}(40-60 \%)$ occurred during this period (DOY 240-260). High rates of $F_{\mathrm{d}}$ in both species were also measured between DOY 330-360. These days corresponded to large daily swings in temperature where nighttime freezing was followed by warm days. High $F_{\mathrm{d}}$ may indicate stomatal damage and loss of stomatal regulation. Two strong freeze events occurred in early January

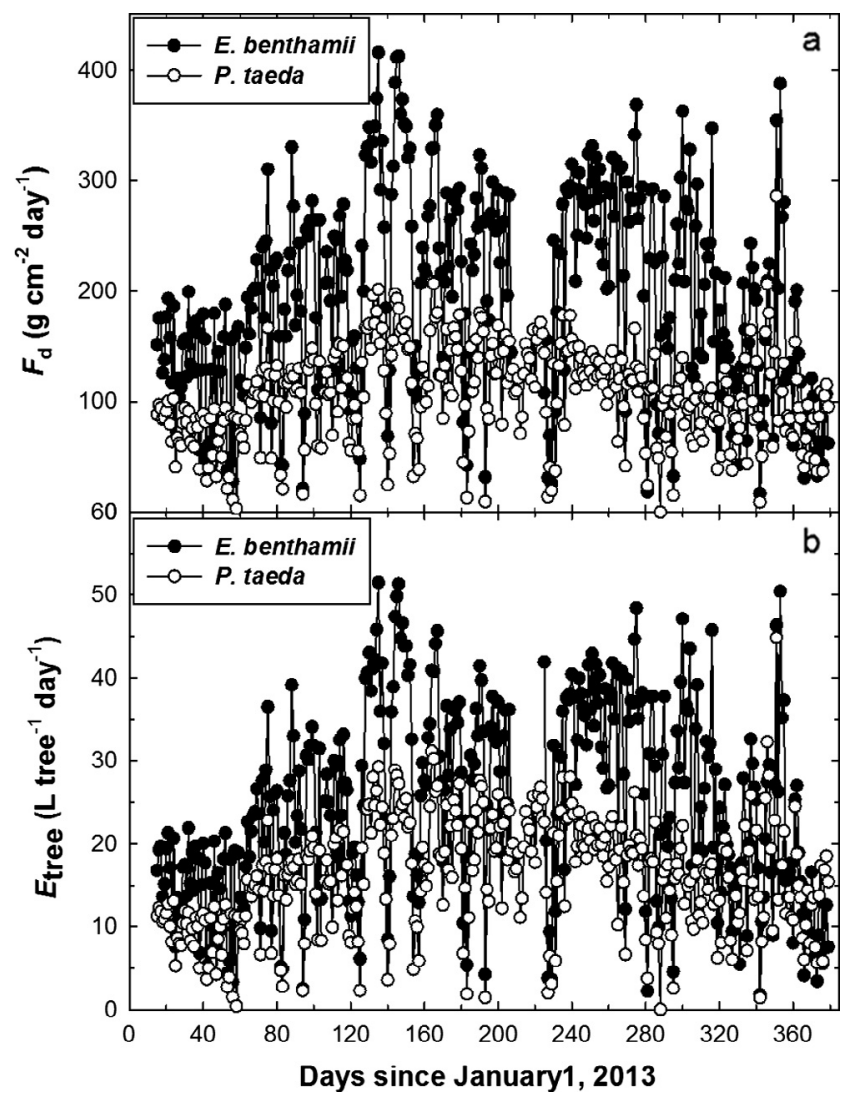

Fig. 6. (a) Mean daily sap flux density $\left(F_{\mathrm{d}}, \mathrm{g} \mathrm{m}^{-2}\right.$ day $\left.^{-1}\right)$ and (b) tree transpiration $E_{\mathrm{t}}$ $\left(\right.$ L tree $^{-1}$ day $^{-1}$ ) in a 9-year-old Eucalyptus and loblolly pine trees. Each point is the mean of 12 (Eucalyptus) and 11 (pine) trees. 
where minimum temperatures were $<-7{ }^{\circ} \mathrm{C}$ (DOY 372-373) and caused crown damage in Eucalyptus. Following these events, $F_{\mathrm{d}}$ was lower in Eucalyptus than pine.

Total daily water use per tree or tree transpiration $\left(E_{\mathrm{t}}\right)$ was also greater in Eucalyptus (Fig. 6b). Mean daily $E_{\mathrm{t}}$ was $24.6 \mathrm{~L} \mathrm{day}^{-1} \mathrm{com}-$ pared to $15.2 \mathrm{~L} \mathrm{day}^{-1}$ for pine ( $\mathrm{SE}=0.46, P<0.001$ ). Mean daily tree transpiration per unit ground area $\left(E_{\mathrm{t}, \mathrm{g}}\right)$ was 3.11 and $2.17 \mathrm{~mm} \mathrm{day}^{-1}$ for Eucalyptus and pine, respectively ( $\mathrm{SE}=0.04$, $P<0.001$ ). Although, Eucalyptus trees were larger, there was no species difference in $A_{\mathrm{s}}$, thus greater tree water use in Eucalyptus was due to greater $F_{\mathrm{d}}$. Nocturnal water use ( $E_{\mathrm{t}, \text { night }}$; $\left.\mathrm{PAR}<5 \mu \mathrm{mol} \mathrm{m} \mathrm{s}^{-2} \mathrm{~s}^{-1}\right)$ was slightly higher in Eucalyptus $\left(0.45 \mathrm{~L} \mathrm{day}^{-1}\right)$ than pine $\left(0.33 \mathrm{~L} \mathrm{day}^{-1}\right)(\mathrm{se}=0.04, P=0.030)$, which corresponded to 2.34 and $2.97 \%$ of daily water use in Eucalyptus and pine, respectively. $E_{\mathrm{t}, \text { night }}$ was linearly correlated with $D$ over a range of $0.05-0.55 \mathrm{kPa}$ (pine: $R^{2}=0.18, P<0.001$; Eucalyptus: $R^{2}=0.29, P<0.001$ ).

The contrasting seasonal patterns of $F_{\mathrm{d}}$ and $E_{\mathrm{t}}$ are better illustrated using monthly-accumulated $E_{\mathrm{t}}\left(\mathrm{m}^{3} \mathrm{H}_{2} \mathrm{O}\right.$ month $\left.{ }^{-1}\right)$ (Fig. 7). Monthly average $E_{\mathrm{t}}$ was $39 \%$ higher for Eucalyptus $\left(0.76 \mathrm{~m}^{3} \mathrm{H}_{2^{-}}\right.$ 0 month $\left.^{-1}\right)$ than pine $\left(0.46 \mathrm{~m}^{3} \mathrm{H}_{2} \mathrm{O}\right.$ month $\left.^{-1}\right) \quad(\mathrm{SE}=0.06$, $P<0.001)$. There was a significant Species $\mathrm{x}$ Month interaction $(P<0.001)$ where the largest monthly difference between species occurred in May $(P<0.001)$, September $(P=0.003)$, and October $(P=0.001)$.

Annual $E_{\mathrm{t}}$ was $9.13 \mathrm{~m}^{3} \mathrm{H}_{2} \mathrm{O}$ year $^{-1}$ for Eucalyptus compared to $5.79 \mathrm{~m}^{3} \mathrm{H}_{2} \mathrm{O}$ year ${ }^{-1}$ for pine $(\mathrm{SE}=0.82, P=0.048)$ and tree $E_{\mathrm{t}, \mathrm{g}}$ was 1077 and $733 \mathrm{~mm} \mathrm{year}^{-1}$ ( $\mathrm{SE}=81, P=0.007$ ) for Eucalyptus and pine, respectively. Annual stem biomass increment and annual tree $E_{\mathrm{t}}$ increased linearly with initial stem mass measured at the beginning of the study (Fig. 8a and b). Interestingly, pine had greater $E_{\mathrm{t}}$ than Eucalyptus at similar stem biomass. Accounting for differences in stem mass, there was no significant difference in $E_{\mathrm{t}}$ (Eucalyptus: 7.3, pine: $7.6 \mathrm{~m}^{3} \mathrm{H}_{2} \mathrm{O}$ year $^{-1}$; $\mathrm{SE}=1.0, P=0.872$ ). Annual $E_{\mathrm{t}}$ was linearly related to stem mass growth in Eucalyptus and pine (Fig. 8c); although, there was no significant difference in the regres$\operatorname{sion}(P>0.05)$. Tree water use efficiency (WUE, $\mathrm{kg} \mathrm{m}^{-3} \mathrm{H}_{2} \mathrm{O}$ ) was calculated as the quotient of annual stem growth $\left(\mathrm{kg} \mathrm{year}^{-1}\right)$ and annual tree water use $\left(\mathrm{m}^{-3} \mathrm{H}_{2} \mathrm{O}\right.$ year $\left.{ }^{-1}\right)$. There was no significant relationship between WUE and tree size (data not shown); however, WUE was negatively correlated with tree height (Fig. 8d). Accounting for species differences in tree height, WUE was significantly greater in Eucalyptus $\left(2.86 \mathrm{~kg} \mathrm{~m}^{-3} \mathrm{H}_{2} 0\right.$ year $\left.{ }^{-1}\right)$ than in pine $\left(1.72 \mathrm{~kg} \mathrm{~m}^{-3} \mathrm{H}_{2} 0\right.$ year $\left.^{-1}\right)(\mathrm{SE}=0.22 ; P=0.004)$.

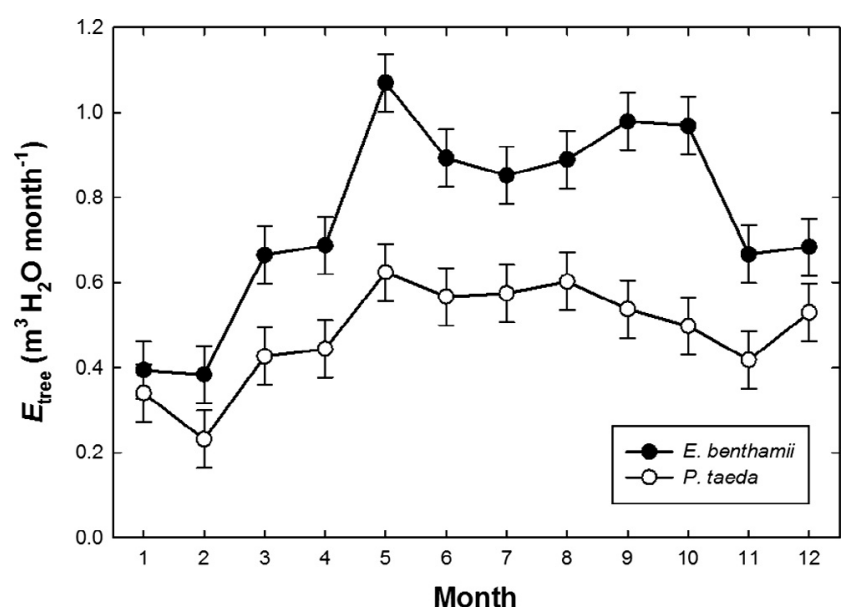

Fig. 7. Monthly mean tree transpiration $\left(E_{\mathrm{t}}, \mathrm{m}^{3}\right.$ tree $^{-1}$ month $\left.{ }^{-1}\right)$ in 9 -year-old Eucalyptus and loblolly pine. Data are least square means and standard errors (Eucalyptus; $n=12$; pine: $n=11$ ).
3.4. Leaf transpiration $\left(E_{l}\right)$, canopy stomatal conductance $\left(G_{s}\right)$, and sensitivity to $D$

Despite large seasonal variation in VWC, there was no relationship between daily $F_{\mathrm{d}}$ and VWC in pine $(P>0.05)$. In Eucalyptus, daily $F_{\mathrm{d}}$ was negatively correlated with VWC $(\mathrm{P}<0.001)$; however, the relationship was weak $\left(R^{2}<0.10\right)$ (data not shown). This pattern was driven primarily by high daily $F_{\mathrm{d}}$ in late spring (DOY 140-160) when VWC was relatively low (Fig. 5).

Leaf transpiration and $G_{s}$, were estimated for early spring (April, DOY 91-120) and late summer (September, DOY 244-273) corresponding to periods of near minimum and maximum $\mathrm{LAI}_{\mathrm{p}}$ (Fig. 1). Mean mid-day (1000-1400 h) $E_{1}$ and $G_{s}$ were significantly greater in Eucalyptus than pine (Table 2); however, there was a Species $x$ Season interaction $\left(E_{1}: P=0.004 ; G_{s}: P=0.007\right)$. Species differences in $E_{1}$ and $G_{s}$ were non-significant in April while rates in Eucalyptus were much greater in September. The diurnal patterns of $E_{1}$ and $G_{\mathrm{s}}$ differed between species and seasons. For example in April, both species had similar diurnal patterns of $E_{1}$ and $G_{s}$, and maximum $G_{\mathrm{s}}$ occurred several hours before maximum $E_{1}$ (Fig. 9c and e). In September, maximum daily $E_{1}$ and $G_{\mathrm{s}}$ in pine occurred earlier in the day relative to $D$ than in Eucalyptus, and $G_{\mathrm{s}}$ declined more rapidly in pine (Fig. $9 \mathrm{~d}$ and f). The time lag between $E_{1}$ and $D$ created a hysteresis in the relationship where at similar $D ; E_{1}$ was greater in the morning than in the afternoon. (Fig. 9c and $\mathrm{d}$ inset). The magnitude of the hysteresis was a function of the time lag between maximum $E_{1}$ and $D$. Average across all days, the time lag between maximum $E_{1}$ and $D$ was similar between species in April (Eucalyptus: 1.38 , pine: $1.52 \mathrm{~h}$; $\mathrm{SE}=0.10$, $P=0.802$ ); however, the time lag increased in September for both species and was significantly greater in pine (Eucalyptus: 1.89, pine: $2.56 \mathrm{~h}$; $\mathrm{SE}=0.10, P<0.001$ ).

Canopy stomatal conductance decreased with $D$ (Fig. 10a) and there was a significant Species $\mathrm{x}$ Season effect in the response to $D\left(G_{\mathrm{s}, \mathrm{ref}}, P=0.004 ;-m, P=0.011\right)$ (Table 3$)$. There was no difference between species in $G_{s, \text { ref }}$ or $-m$ in April, however Eucalyptus had significantly greater $G_{\mathrm{s}, \text { ref }}$ in September. There was a significant linear relationship between $-m$ and $G_{\mathrm{s}, \mathrm{ref}}$ in both species $(P<0.001)$ (Fig. 10b) and pine had a higher ratio between $-m$ and $G_{s, r e f}$ than Eucalyptus in April (pine: 0.845; Eucalyptus: 0.611; $P=0.002$ ) and September (pine: 0.830; Eucalyptus: 0.675; $P=0.003$ ). At similar $G_{s, \text { ref, }}$ pine appeared to have greater sensitivity to $D$ than Eucalyptus.

\section{Discussion}

\subsection{TDP calibration}

In pine, the standard Granier equation estimated cumulative water use within $13 \%$ of the observed measured with the potometer and the relationship between $F_{\mathrm{d}, \mathrm{g}}$ and $F_{\mathrm{d}, \mathrm{p}}$ was near unity. In contrast, the standard equation severely underestimated sap flow in Eucalyptus. A highly significant but nonlinear correlation between $F_{\mathrm{d}, \mathrm{g}}$ and $F_{\mathrm{d}, \mathrm{p}}$ enabled adjustment of $F_{\mathrm{d}, \mathrm{g}}$ to predict sap flow in Eucalyptus (Fig. 3b). The TDP probes appear to lose sensitivity when $F_{\text {d.p }}$ exceeded $250 \mathrm{~g} \mathrm{~m}^{-2} \mathrm{~s}^{-1}$. These results suggest that for some species, potometers may generate high sap flow rates, perhaps because resistance at the soil-root interface to water uptake is not a factor (i.e. cut trees may have artificially high sap flow rates that do not occur in trees with intact roots). This same factor could also influence potometer based sap flow estimates in pine; however, alteration of the resistance at the soil-root interface did not appear to influence water uptake in pine in the same way it affected Eucalyptus. The extent to which the potometer-based calibration procedure affected results in our study is unknown; 

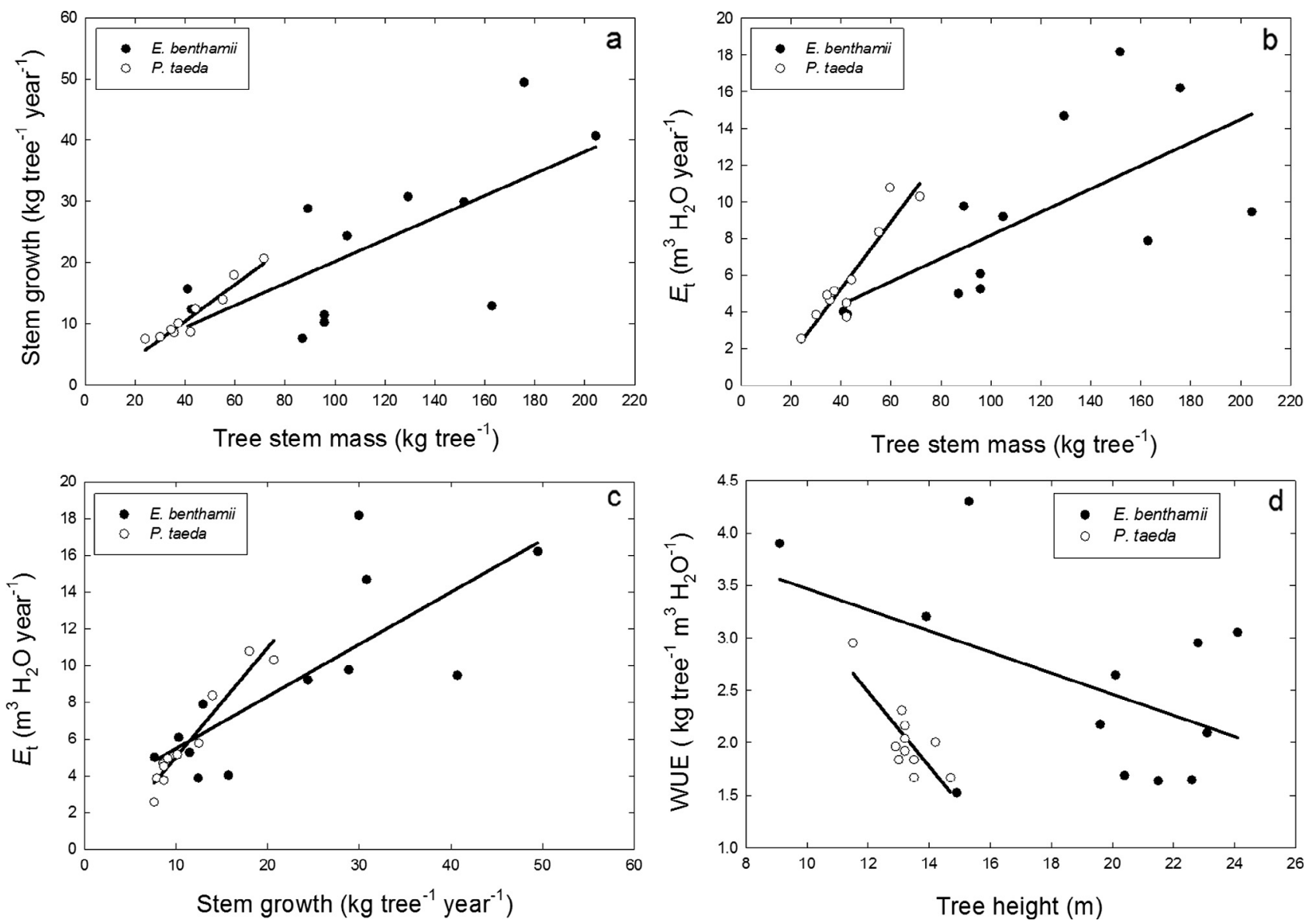

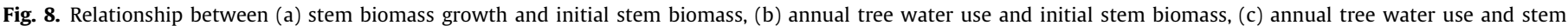
biomass growth, and (d) tree water use efficiency (WUE) and tree height.

Table 2

Mean mid-day (1000-1400 h) leaf transpiration $\left(E_{1}, \mathrm{mmol} \mathrm{m}^{-2} \mathrm{~s}^{-1}\right)$ and canopy stomatal conductance $\left(G_{\mathrm{s}}, \mathrm{mmol} \mathrm{m} \mathrm{m}^{-2} \mathrm{~s}^{-1}\right.$; PAR $\left.>1200 \mu \mathrm{mol} \mathrm{m}^{-2} \mathrm{~s}^{-1}\right)$ measured in April (DOY 91-120) and September (DOY 244-273). Data are LSMEANs and standard error in parentheses.

\begin{tabular}{llll}
\hline Month & Species & $E_{1}$ & $G_{\mathrm{s}}$ \\
\hline April & E. benthamii & $2.11 \mathrm{ab}^{1}$ & $188.6 \mathrm{a}$ \\
& $P$. taeda & $1.84 \mathrm{~b}$ & $165.7 \mathrm{a}$ \\
September & E. benthamii & $2.80 \mathrm{a}$ & $198.3 \mathrm{a}$ \\
& P. taeda & $1.29 \mathrm{c}$ & $84.4 \mathrm{~b}$ \\
& & $(0.26)$ & $(20.7)$ \\
\hline
\end{tabular}

${ }^{1}$ Within column, means followed by different letters denote significant differences at $\alpha=0.05$.

however, $F_{\mathrm{d}, \mathrm{g}}$ above $120 \mathrm{~g} \mathrm{~m}^{-2} \mathrm{~s}^{-1}$ was rarely observed in intact Eucalyptus trees. Our results corroborate other studies that suggest the original Granier calibration underestimates sap flow in Eucalyptus. For example, a fivefold underestimate from the standard equation was observed in four year-old $E$. grandis $\times$ urophylla hybrids (Hubbard et al., 2010) and, similar to our study, a threefold underestimate was observed for three-year-old E. globulus and $E$. nitens $x$ globulus hybrid trees (Rubilar et al., 2017).

\section{2. $F_{d}, E_{t}$ and $W U E$}

Mean daily $E_{\mathrm{t}}$ and $E_{\mathrm{t}, \mathrm{g}}$ were significantly greater in Eucalyptus than pine. Although Eucalyptus trees were larger, there was no significant difference in $A_{\mathrm{s}}$, therefore greater $E_{\mathrm{t}}$ in Eucalyptus was due greater $F_{\mathrm{d}}$. Pine $E_{\mathrm{t}}$ and $E_{\mathrm{t}, \mathrm{g}}$ were similar to plantation grown trees in other studies in the Southern US. For example, Samuelson and Stokes (2006) reported $1.5 \mathrm{~mm} \mathrm{day}^{-1}$ for control plots and $2.4 \mathrm{~mm} \mathrm{day}^{-1}$ for plots receiving weed control, irrigation, and fertilization. Gonzalez-Benecke and Martin, 2010) reported maximum $E_{\mathrm{t}}$ of 2.6 and $4.3 \mathrm{~mm} \mathrm{day}^{-1}$ for non-irrigated and irrigated stands, respectively, although the trees were much larger than in our study. Higher rainfall (19\% greater than average) could have driven higher $E_{\mathrm{t}}$ (Stape et al., 2004). We are aware of no sap flow estimates of $E_{\mathrm{t}}$ for $E$. benthamii; however, the values measured in this study are comparable with sap flow rates reported for other plantation grown Eucalyptus species (Whitehead and Beadle, 2004). Dye (2013) reported daily $E_{\mathrm{t}}$ for nine-year-old $E$. grandis that ranged between 2.0-7.5 mm day ${ }^{-1}$ and 30.9-64.3 $\mathrm{L} \mathrm{tree}^{-1}$ and under high $D$ could exceed $90 \mathrm{~L}^{\text {tree }}{ }^{-1}$.

There was a Species $\mathrm{x}$ Month interaction where Eucalyptus exhibited a seasonally bimodal pattern in daily $E_{\mathrm{t}}$ that did not occur in pine. This seasonal pattern in $E_{\mathrm{t}}$ is likely related to differences in growth dynamics. For example, diameter growth in pine ceased by early fall (DOY 280), whereas, stem growth in Eucalyptus was continuous throughout the study (Fig. 5). Furthermore, we observed 20-60\% greater net photosynthesis in E. benthamii compared to $P$. taeda, and Eucalyptus was able to maintain high photosynthetic rates even in winter (K. Johnsen unpublished data). Eucalyptus had significantly higher $E_{\mathrm{t} \text {,night }}$; however, the proportion of total daily flow was low $(<3.5 \%)$ in both species. Nocturnal transpiration was lower than reported for E. grandis (5\%, Benyon, 1999) and P. taeda (11\%, Oishi et al., 2008), although the trees were larger in these studies. Gonzalez-Benecke et al. (2011) found that $E_{\text {night }}$ ranged from $6-8 \%$ of total daily water use in P. elliottii and P. palustris. 

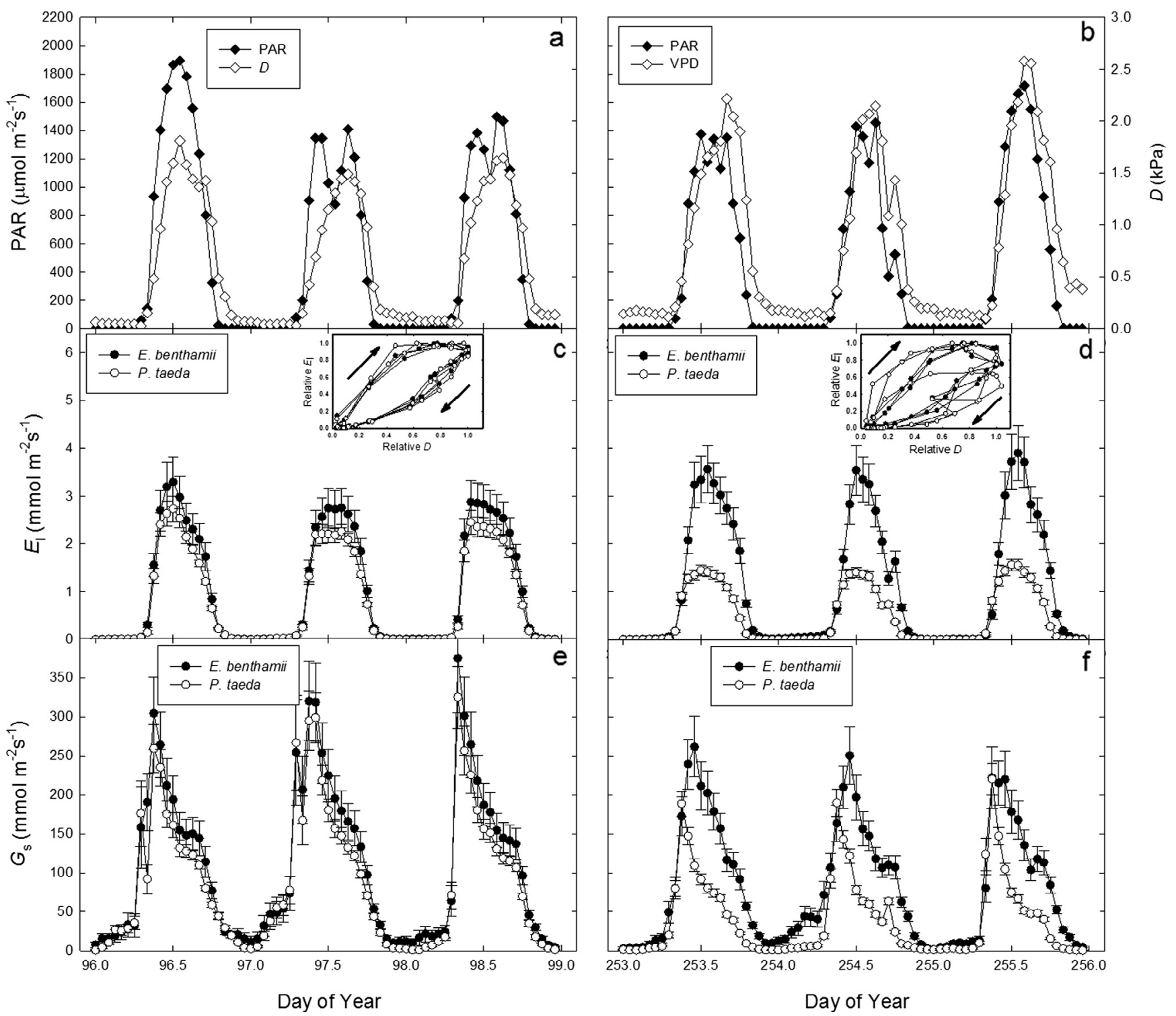

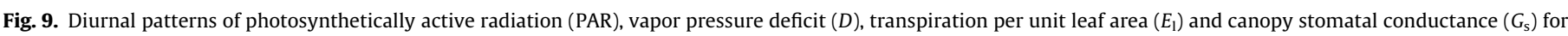

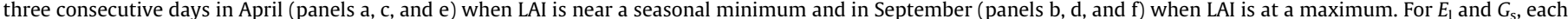
data point is the mean ( $\pm \mathrm{SE}$ ) of 12 (Eucalyptus) or 11 (pine) trees. Insets in panels $\mathrm{c}$ and d show the diurnal time course (arrows) in the relationship between $E_{1}$ and $D$.

On an annual basis, Eucalyptus trees used $32 \%$ more water $\left(9.1 \mathrm{~m}^{3} \mathrm{H}_{2} \mathrm{O}\right.$ year ${ }^{-1}, 1077 \mathrm{~mm}$ year $\left.^{-1}\right)$ than pine $\left(5.8 \mathrm{~m}^{3} \mathrm{H}_{2} \mathrm{O}\right.$ year ${ }^{-1}$, $733 \mathrm{~mm}$ year $^{-1}$ ). This corresponded to 66 and $45 \%$ of annual precipitation for Eucalyptus and pine, respectively. Gonzalez-Benecke and Martin (2010) measured annual $E_{\mathrm{t}}$ of $930 \mathrm{~mm}$ in irrigated loblolly pine which was $54 \%$ of total input (precipitation + irrigation). Hubbard et al. (2010) found that monthly $E_{\mathrm{t}}$ ranged from $\approx 150 \mathrm{~mm}$ to over $250 \mathrm{~mm}$ during the growing season in five-year-old $E$. grandis $\times$ urophylla plantations. In these same stands, annual $E_{\mathrm{t}}$ was 1394 and $1779 \mathrm{~mm}$ in rain-fed and irrigated stands, respectively. Dye et al. (2004) reported annual $E_{\mathrm{t}}$ ranging from 900 to $1400 \mathrm{~mm}$ in E. grandis $\times$ camaldulensis.

Pine had greater $E_{\mathrm{t}}$ at similar stem mass than Eucalyptus (Fig. 8b). Accounting for differences in tree size, there was no significant difference in annual water use (Eucalyptus: 7.3, pine: $7.6 \mathrm{~m}^{3} \mathrm{H}_{2} \mathrm{O}$ year ${ }^{-1}$ ). Differences in stand development stage may explain this response. The Eucalyptus was at more advance stage of development, while the pine stand was at an age and stocking $\left(\mathrm{BA}=22 \mathrm{~m}^{2} \mathrm{ha}^{-1}\right.$ ) where foliage biomass production, leaf area, and total tree water use had just stabilized (Albaugh et al., 2004;
Martin and Jokela, 2004). As stem mass increases, water use per unit stem mass should decrease. We found no relationship between WUE and stem biomass as reported in other studies (Forrester et al., 2012; Otto et al., 2014); however, there was negative correlation with tree height, which is consistent with increased stem hydraulic resistance in taller trees (Hubbard et al., 1999). Correcting for height effects, Eucalyptus trees were $40 \%$ more water use efficient than pine (Eucalyptus: 2.9; pine: $1.7 \mathrm{~kg} \mathrm{~m}^{-3} \mathrm{H}_{2} \mathrm{O}$ tree $^{-1}$ ). Eucalyptus WUE in this study was within the range reported for Eucalyptus sp (Albaugh et al., 2013; Hubbard et al., 2010; Forrester et al., 2010; White et al., 2016). Samuelson and Stokes (2006) reported WUE ranged between 1.18-1.62 $\mathrm{kg} \mathrm{m}^{-3} \mathrm{H}_{2} \mathrm{O}$ in five year-old irrigated and fertilized loblolly pine.

\subsection{Leaf transpiration $\left(E_{l}\right)$ and canopy stomatal conductance $\left(G_{s}\right)$}

Eucalyptus had greater $E_{1}$ and $G_{\mathrm{s}}$ than pine; though, there was a significant Species $\times$ Season interaction. Leaf transpiration, $G_{\mathrm{s}}$ and response to $D$ were similar between species in the spring; however, 

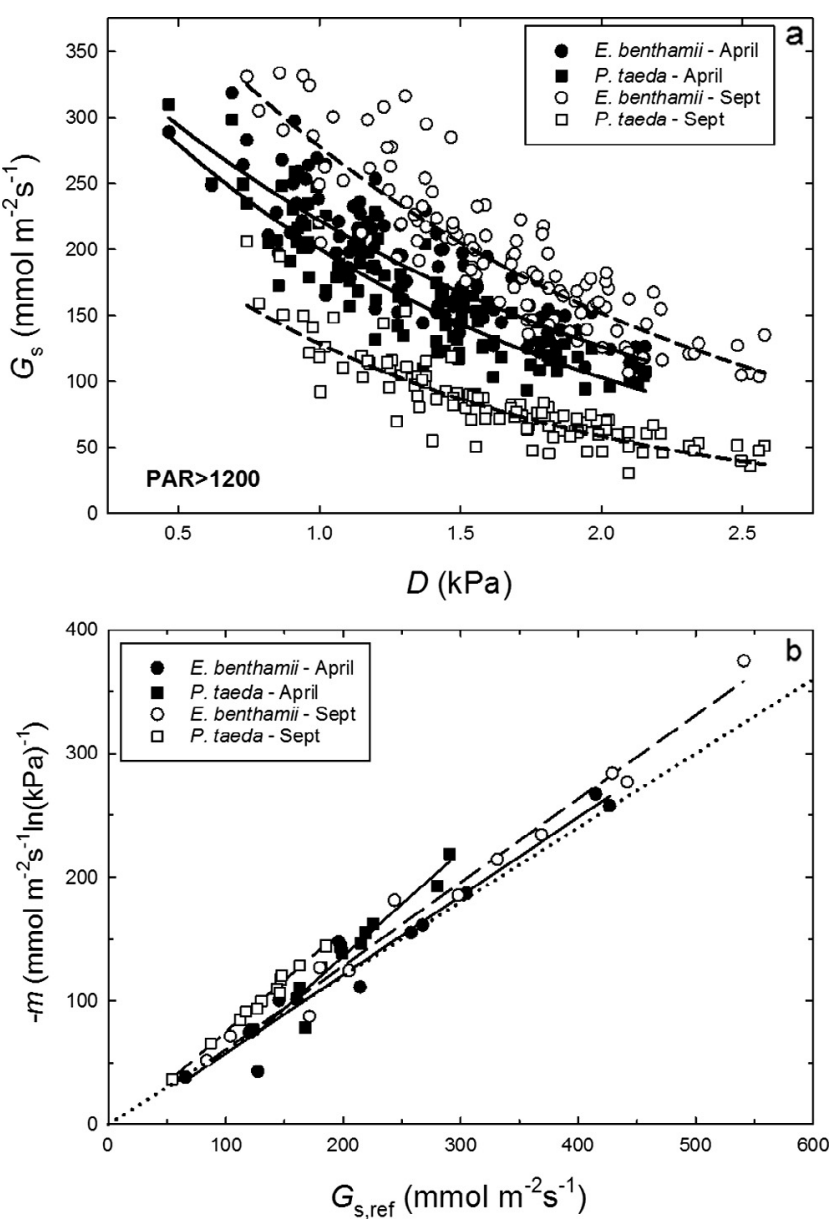

Fig. 10. Relationship between (a) canopy stomatal conductance $\left(G_{\mathrm{s}}\right)$ and air vapor pressure deficit $(D)$ and $(\mathrm{b})$ the sensitivity $(-m)$ of canopy stomatal conductance to $D$ and $G_{\mathrm{s}}$ at $D$ at $1 \mathrm{kPa}\left(G_{\mathrm{s}, \mathrm{ref}}\right)$ in nine-year-old Eucalyptus and pine. In panel a, data are at PAR $>1200 \mu \mathrm{mol} \mathrm{m}{ }^{-2} \mathrm{~s}^{-1}$. Each data point is the mean of 12 (Eucalyptus) or 11 (pine) trees. The dotted line is the theoretical 0.6 ratio between $-m$ and $G_{\mathrm{s}, \mathrm{ref}}$ (Oren et al., 1999).

Table 3

Parameter estimates for canopy stomatal conductance response to vapor pressure deficit $(D)$ (Eq. (4)) when $D>0.75 \mathrm{kPa}$ and PAR $>1200 \mu \mathrm{mol} \mathrm{m}^{-2} \mathrm{~s}^{-1}$. $G_{\text {ref }}$ is reference stomatal conductance and $-m$ is the rate of decrease in $G_{s}$ per unit of $D$. Data are LSMEANs and standard error in parentheses.

\begin{tabular}{llll}
\hline Month & Species & $G_{\mathrm{ref}}$ & $-m$ \\
\hline April & E. benthamii & $230.6 \mathrm{ab}^{1}$ & $142.7 \mathrm{ab}$ \\
& P. taeda & $201.9 \mathrm{bc}$ & $137.7 \mathrm{ab}$ \\
September & E. benthamii & $283.1 \mathrm{a}$ & $184.4 \mathrm{a}$ \\
& P. taeda & $129.9 \mathrm{c}$ & $99.9 \mathrm{~b}$ \\
& & $(27.7)$ & $(18.9)$
\end{tabular}

${ }^{1}$ Within column, means followed by different letters denote significant differences at $\alpha=0.05$.

in September $E_{1}$ and $G_{\mathrm{s}}$ increased in Eucalyptus while the opposite was observed in pine. As expected, there was a curvilinear relationship between $G_{\mathrm{s}}$ and $D$, and $G_{\mathrm{s}}$ sensitivity to $D$ varied with species and time of year. Understanding species differences in $G_{s}$ is critical as it controls $E_{1}$ and is tightly linked to carbon assimilation (Franks and Farquhar, 1999). Oren et al. (1999) analyzed $G_{\mathrm{s}, \text { ref }}$ and $-m$ across a range of species and found that $-m / G_{\mathrm{s}, \mathrm{ref}}=0.6$ and theorized that isohydric species maintain this ratio to regulate a minimum leaf water potential to prevent excessive $E_{1}$ and xylem cavitation. Averaged across season, $G_{\mathrm{s}, \mathrm{ref}}$ and $-m$ was greater in Eucalyptus; however, at similar $G_{\mathrm{s}, \mathrm{ref}}$, pine had greater sensitivity to $D$ as indicated by the significantly greater $-m / G_{\mathrm{s}, \text { ref }}$ in pine ( 0.84 vs 0.62 for pine and Eucalyptus, respectively). In pine, $-m$ / $G_{s, \text { ref }}$ was significantly greater than the theoretical 0.6 which contrast with other studies for this species (Ewers et al., 2000; Samuelson et al., 2008; Gonzalez-Benecke et al., 2011). Values greater than the 0.6 proportionality may result from poor atmospheric coupling or high ratio between boundary layer and stomatal conductance (Oren et al., 1999).

The contrasting patterns between species in $E_{1}, G_{s}$, and response to $D$ are likely due to species differential response to soil moisture and to different seasonal patterns of tree leaf area. We found little or no relationship between $F_{\mathrm{d}}$ and soil moisture probably because soil VWC rarely reach a limiting level. Reductions in canopy conductance in loblolly pine usually do not develop until plant available soil water falls below 30\% (Gonzalez-Benecke and Martin, 2010). In our study, this threshold would be at 0.14 VWC, which did not occur for much of the growing season. However, this not to say the soil moisture had no effect on tree water use. Diurnal changes in $E_{1}$ typically lag behind $D$ creating a clockwise hysteresis pattern where at a similar $D, E_{1}$ is greater in the morning than in the afternoon (Meinzer et al., 1997). The magnitude of the hysteresis is a function of lag time between $E_{1}$ and $D$ and has been attributed to low soil hydraulic conductivity and reduced stem capacitance (i.e. stored water) (O'Grady et al., 1999). Analysis of the lag times showed that pine had a significantly greater lag time compared to Eucalyptus in September, when VWC ranged from 0.14-0.19 than in April when VWC ranged from $0.22-0.24$. These results suggest that lower VWC in September may have affected water uptake and lowered stem capacitance to a greater extent in pine than Eucalyptus.

Seasonal leaf area dynamics may have also influence species differences in $E_{1}$ and $G_{\mathrm{s}}$. Eucalyptus $\mathrm{LAI}_{\mathrm{T}}$ increased $22 \%$ from spring to fall compared to an $83 \%$ increase in pine. The large increase in LAI likely reduced $A_{s}: A_{1}$. Water transport is dependent on $A_{s}: A_{1}$, plant hydraulic conductivity, and leaf water potential (Whitehead et al., 1984), and $G_{\mathrm{s}}$ is sensitive to reductions in stem and leaf hydraulic conductivity (Meinzer, 2002). In order to prevent low leaf water potential and leaf damage, increased leaf area must be accompanied by a proportional increase in $A_{s}$, or a reduction in whole-tree and leaf hydraulic conductance (Whitehead, 1998). For example, Samuleson et al. (2006) showed that fertilizing young loblolly pine plantations resulted in a large increase in leaf area and $A_{s}: A_{1}$, but had no effect on $G_{s}$, tree hydraulic conductance, or leaf water potential. On the other hand, Ewers et al. (2000) found that increased leaf area in fertilized loblolly pine was accompanied by reduced $A_{s}: A_{1}$, but the trees maintained leaf water potential, primarily through decreased $G_{s}$ and tree hydraulic conductance. In the current study, reduced $E_{1}$ and $G_{s}$ and the more rapid diurnal decline in $G_{s}$ in pine observed in September suggest a seasonal adjustment in tree or leaf hydraulic conductance. The mechanism for increased Eucalyptus $E_{1}$ and $G_{s}$ in the fall is unknown.

Water use in fast growing Eucalyptus and loblolly pine plantations is strongly correlated to leaf area (Whitehead and Beadle, 2004; Samuelson et al., 2008). Myers et al. (1996) reported 22\% higher rates of evapotranspiration in three-year-old plantations of E. grandis than in P. radiata. Similarly, Moreaux et al. (2012) found $25 \%$ higher $E_{\mathrm{t}}$ in five-year-old $E$. gunni $x$ dalrympleana plantations compared to native $P$. pinaster. Species differences in water use were attributed to differences in stand growth, stage of development, and leaf area. Our results contrast with these studies. Annual $E_{\mathrm{t}}$ was $25 \%$ higher in Eucalyptus, similar to the above studies; however, while pine exhibited a larger seasonal range in LAI, average (winter + summer) LAI was similar between species (Eucalyptus: 2.66 ; pine: 2.87 ). Thus, differences in water use were largely a function of species differences in $E_{1}$ and $G_{\mathrm{s}}$ 


\subsection{Species differences in evapotranspiration}

We did not measure water loss from canopy interception or soil evaporation; however, these components can account for up to 10$45 \%$ of stand evapotranspiration (ET $=E_{\mathrm{t}}+$ interception + soil evaporation) and must be considered when evaluating the stand water balance and effects on off-site water yield. Interception varies widely depending on canopy architecture, stand LAI, and rainfall intensity. These factors make it difficult to generalize; however, because of crown architecture, leaf shape and display, conifers typically have greater interception losses than hardwoods (Cannell, 1999). Using published estimates of interception loss for Eucalyptus (11\%, Soares and Almeida, 2001) and loblolly pine (15\%, Sun et al., 2010), interception losses would be 179 and $245 \mathrm{~mm}$, respectively. Under these conditions, species differences in stand ET (1256 vs $997 \mathrm{~mm}$ for Eucalyptus and pine, respectively) would be lower relative to tree-level $E_{\mathrm{t}}$. On the other hand, soil evaporation is probably higher in Eucalyptus potentially offsetting species differences in interception. Benyon and Doody (2015) compared interception and soil evaporation across 18 plantations of E. globulus and $P$. radiata and reported higher interception but lower soil evaporation losses for pine such that the relative contribution of interception and soil evaporation was similar between species, $46-48 \%$ of precipitation.

Estimated pine ET and the ratio ET/P $(0.61)$ is within the range reported for loblolly pine plantations with similar stem density and leaf area as the stand in this study (Amatya et al., 2006; Sun et al., 2010; Domec et al., 2012). High ET/P has been reported for fast growing Eucalyptus. Almeida et al. (2007) estimated that ET of E. grandis in Brazil over a 6-year rotation used 95\% of precipitation. Similarly, Cabral et al. (2010) reported that ET/P ranged from 0.82 to 0.96 in a young clonal E. grandis $x$ urophylla plantation and Abichou et al. (2012) estimated ET/P of 0.81 for E. amplifolia. Under well-watered, closed canopy conditions, forest evapotranspiration can equal PET (Rutter, 1968). It was unlikely that these stands experienced drought as precipitation was well above average during the growing season. However, it is unknown how $E_{\mathrm{t}}$ and ET would differ under drought conditions. Eucalyptus spp. are typically deeper rooting than pine (Canadell et al., 1996) and can often rely on groundwater to drive $E_{\mathrm{t}}$ (Morris and Collopy, 1999) under dry conditions.

\subsection{Implications}

Our results suggest that young Eucalyptus plantations will have greater WUE than pine; however, because of greater growth potential, $E_{1}$, and $G_{s}$, total water use will be higher. Furthermore, Eucalyptus will likely be managed on shorter rotations ( $6-8$ years) and will have greater cumulative water use over successive rotations compared to conventionally managed pine with longer rotations (1525 years). Thus, species conversion from pine to Eucalyptus may adversely affect off-site water yield. The scale and location of plantation establishment will determine impacts on water yield at the catchment or landscape level. For example, Vose et al. (2015) evaluated stand- and regional-level implications of converting forest from pine to Eucalyptus on water yield across the southern United States (plant hardiness zones $8 \mathrm{~b}$ and higher). Accounting for species differences in $E_{\mathrm{t}}$ (Penman-Monteith equation) and site variation in climate and hydrology, they concluded that converting pine to Eucalyptus could reduce stand-level water yield by up to $250 \mathrm{~mm}$ year $^{-1}$ (48\%) on some sites. Base on economic factors of Eucalyptus cultivation, Wear et al. (2015) concluded that less than $3 \%$ of the potential land base would be used for Eucalyptus production. At this scale, the likely impacts of Eucalyptus on regional water supplies would be small. Nevertheless, higher absolute water use by intensively managed Eucalyptus forests could have negative local-scale impacts on stream flow or ground water reserves in water limited or ecologically sensitive areas (Albaugh et al., 2013; Vose et al., 2015).

\section{Conclusions}

We found that Eucalyptus trees had $94 \%$ greater stem growth, $32 \%$ greater tree water use $\left(E_{\mathrm{t}}\right)$, and $40 \%$ greater WUE than pine supporting part of our hypothesis. Species difference in WUE was likely a function of different carbon allocation strategies as Eucalyptus trees appeared to have poorer stomatal regulation of $E_{\mathrm{t}}$. Differences in LAI were small, thus greater $E_{\mathrm{t}}$ in Eucalyptus was largely due to higher $E_{1}$ and $G_{s}$. Eucalyptus and pine trees exhibited different stomatal behavior to $D$. While Eucalyptus had higher average $G_{s}$, ref, at a similar $G_{\mathrm{s}, \mathrm{ref}}$, pine had greater sensitivity to $D$ probably due to seasonal changes in hydraulic architecture. These patterns were observed when precipitation was above normal with most of the excess rainfall occurring during the growing season. Consequently, low soil moisture and high $D$ rarely occurred. Species-specific variance in $E_{\mathrm{t}}$ and the response of $E_{1}$ and $G_{\mathrm{s}}$ to $D$ may differ under water limited conditions. A better understanding of species differences in $G_{\mathrm{s}}$ and response to $D$ and soil moisture is critical as it controls $E_{1}$ and is tightly linked to carbon assimilation.

We only measured $E_{\mathrm{t}}$, but the question of which species has greater impact on water resources must consider losses from canopy interception and soil evaporation. Potentially greater pine interception losses may minimize species differences in standlevel water use. A better understanding of $E_{\mathrm{t}}$, interception, and evaporation within a stand developmental context is important for modeling water use and predicting species effects on stand water dynamics under short rotation culture.

\section{Conflict of interest}

The author declares he has no conflict of interest.

\section{Funding}

This research did not receive any specific grant from funding agencies in the public, commercial, or not-for-profit sectors.

\section{Acknowledgements}

The authors would like to thank Steve Patterson for providing study information and access to the field site in South Carolina and to Pete Anderson, Robert Eaton, and Tom Christensen for technical assistance. The senior author also thanks Drs. Ram Oren and Robert Teskey for helpful discussions on the use of potometers and TDP calibration. This article was written and prepared in part by $U$. S. Government employees on official time, and the textual content is therefore in the public domain and not subject to copyright.

\section{References}

Abichou, T., Musagasa, J., Yuan, L., Chanton, J., Tawfiq, K., Rockwood, D., Licht, L. 2012. Field performance of alternative landfill covers vegetated with cottonwood and eucalyptus trees. Int. J. Phytorem. 14, 47-60.

Albaugh, J.M., Dye, P.J., King, J.S., 2013. Eucalyptus and water use in South Africa. Int. J. Forest Res.

Albaugh, T.J., Allen, H.L., Dougherty, P.M., Kress, L.W., King, J.S., 1998. Leaf area and aboveg- and belowground growth responses of loblolly pine to nutrient and water relations. For. Sci. 44, 317-328.

Albaugh, T.J., Allen, H.L., Dougherty, P.M., Johnsen, K.H., 2004. Long term growth responses of loblolly pine to optimal nutrient and water resource availability. For. Ecol. Manage. 192, 3-19.

Almeida, A.C., Soares, J.V., Landsberg, J.J., Rezende, G.D., 2007. Growth and water balance of Eucalyptus grandis hybrid plantations in Brazil during a rotation for pulp production. For. Ecol. Manage. 251, 10-21.

Amatya, D.M., Joyner, D.F. Skaggs, R.W., Gilliam, J.W., 2006. Hydrologic and Water Quality Effects of Thinning a Drained Pine Plantation in Coastal North Carolina 
in, Hydrology and Management of Forested Wetlands. In: Proceedings of the International Conference. American Society of Agriculutral and Biological Engineers.

Benyon, R.G., 1999. Nighttime water use in an irrigated Eucalyptus grandis plantation. Tree Physiol. 19, 853-859.

Benyon, R.G., Doody, T.M., 2015. Comparison of interception, forest floor evaporation and transpiration in Pinus radiata and Eucalyptus globulus plantations. Hydrol. Process. 29, 1173-1187.

Bush, S.E., Hultine, K.R., Sperry, J.S., Ehleringer, J.R., 2010. Calibration of thermal dissipation sap flow probes for ring- and diffuse-porous trees. Tree Physiol. 30, 1545-1554.

Cabral, O.M.R., Rocha, H.R., Gash, J.H.C., et al., 2010. The energy and water balance of a Eucalyptus plantation in southeast Brazil. J. Hydrol. 388, 208-216.

Calder, I.R., 2002. Eucalyptus, water and the environment. In: Coppen, J.J.W. (Ed.), Eucalyptus: The Genus Eucalyptus.

Callaham, M.A., Stanturf, J.A., Hammond, W., Rockwood, D.L., Wenk, E.S., O’Brien, J.J. 2013. Survey to evaluate escape of eucalyptus spp. seedlings from plantations in southeastern USA. Int. J. Forest. Res. http://dx.doi.org/10.1155/2013/946374.

Canadell, J., Jackson, R.B., Ehleringer, J.B., Mooney, H.A., Sala, O.E., Schulze, E.-D., 1996. Maximum rooting depth of vegetation types at the global scale. Oecologia 108, 583-595.

Cannell, M.G.R., 1999. Environmental impacts of forest monocultures: water use acidification, wildlife conservation, and carbon storage. New Forest. 17, 239262.

Clearwater, M.J., Meinzer, F.C., Andrade, J.L., Goldstein, G., Holbrook, N.M., 1999. Potential errors in measurement of nonuniform sap flow using heat dissipation probes. Tree Physiol. 19, 681-687.

Domec, J.C., Sun, G., Noormets, A., Gavazzi, M.J., et al., 2012. A comparison of three methods to estimate evapotranspiration in two contrasting loblolly pine plantations: age-relatyed changes in water use and drought sensitivity of evapotranspiration components. For. Sci. 58, 497-512.

Dougherty, D., Wright, J., 2012. Silviculture and economic evalution of eucalypt plantations in the Southern US. BioResources 7, 1994-2001.

Dye, P., 2013. A review of changing perspectives on Eucalyptus water-use in South Africa. For. Ecol. Manage. 301, 51-57.

Dye, P.J., Jacobs, S., Drew, D., 2004. Verification of 3-PG growth and water-use predictions in twelve Eucalyptus plantation stands in Zululand, South Africa. For. Ecol. Manage. 193, 197-218.

Ewers, B.E., Oren, R., 2000. Analyses of assumptions and errors in the calculation of stomatal conductance from sap flux measurements. Tree Physiol. 20, 579-589.

Ewers, B.E., Oren, R., Sperry, J.S., 2000. Influence of nutrient versus water supply on hydraulic architecture and water balance. Plant, Cell Environ. 23, 1055-1066.

Farley, K.A., Jobbagy, E.G., Jackson, R.B., 2005. Effects of afforestation on water yield: a global synthesis with implications for policy. Glob. Change Biol. 11, 1565 1576.

Ferraz, S.F.B., Lima, W.d.P., Rodrigues, C.B., 2013. Managing forest plantation landscapes for water conservation. For. Ecol. Manage. 301, 58-66.

Ford, C.R., Goranson, C.E., Mitchell, R.J., Will, R.E., Teskey, R.O., 2004. Diurnal and seasonal variability in the radial distribution of sap flow: predicting total stem flow in Pinus taeda trees. Tree Physiol. 24, 951-960.

Forrester, D.I., Collopy, J.J., Morris, J.D., 2010. Transpiration along an age series of Eucalyptus globulus plantations in southeastern Australia. For. Ecol. Manage. 259, 1754-1760.

Forrester, D.I., Collopy, J.J., Beadle, C.L., Warren, C.R., Baker, T.G., 2012. Effect of thinning, pruning and nitrogen fertiliser application on transpiration, photosynthesis and water-use efficiency in a young Eucalyptus niten plantation. For. Ecol. Manage. 266, 286-300.

Fox, T.R., Jokela, E.J., Allen, H.L., 2007. The development of pine plantation silviculture in the southern United States. J. Forest. 105, 337-347.

Franks, P.J., Farquhar, G.D., 1999. A relationship between humidity response, growth form and photosynthetic operating point in C3 plants. Plant, Cell Environ. 22, 1337-1349.

Gonzalez-Benecke, C.A., Martin, T.A., 2010. Water availability and genetic effects on water relations of loblolly pine (Pinus taeda) stands. Tree Physiol. 30, 376-392.

Gonzalez, R., Treasure, T., Wright, J., Saloni, D., Phillips, R., Abt, R., Jameel, H., 2011 Exploring the potential of Eucalyptus for energy production in the southern United States: financial analysis of delivered biomass. Part 1. Biomass Bioenerg. $35,755-766$

Gonzalez-Benecke, C.A., Martin, T.A., Cropper, W.P., 2011. Whole-tree water relations of co-occuring mature Pinus palustris and Pinus elliottii var. elliottii. Can. J. For. Res. 41, 509-523.

Granier, A., 1985. Une nouvelle methode pour la measure du flux de seve brute dans le tronc des arbres. Annales Des Sci. Forest. 42, 193-200.

Gutiérrez, M.V., Santiago, L.S., 2006. A comparison of sap flow measurements and potometry in two tropical lowland tree species with contrasting wood properties. Rev. Biol. Trop. 54, 73-81.

Hall, K.B., 2015. Modeling the Actual Productivity of Eucalyptus benthamii in the Southeastern United States PhD Dissertation. North Carolina State University. $145 \mathrm{p}$.

Hatton, T.J., Catchpole, E.A., Vertessy, R.A., 1990. Integration of sapflow velocity to estimate plant water use. Tree Physiol. 6, 200-209.

Hinchee, M., Rottmann, W., Mullinax, L., Zhang, C., Chang, S., Cunningham, M. Pearson, L., Nehra, N., 2009. Short-rotation woody crops for bioenergy and biofuels applications. In Vitro Cell. Develop. Biol. 45, 619-629.

Hubbard, R.M., Bond, B.J., Ryan, M.G., 1999. Evidence that hydraulic conductance limits photosynthesis in old Pinus ponderosa trees. Tree Physiol. 19, 165-172.
Hubbard, R.M., Stape, J., Ryan, M.G., Almeida, A.C., Rojas, J., 2010. Effects of irrigation on water use and water use efficiency in two fast growing Eucalyptus plantations. For. Ecol. Manage. 259, 1714-1721.

Hultine, K.R., Nagler, P.L., Morino, K., Bush, S.E., Burtch, K.G., Dennison, P.E., Glenn, E. P., Ehleringer, J.R., 2010. Dap flux-scaled transpiration by tamarisk (Tamarix spp.) before, during and after episodic defoliation by the saltcedar leaf beetle (Diorhabda carinulata). Agric. For. Meteorol. 150, 1467-1475.

Jackson, R.B. et al., 2005. Trading water for carbon with biological carbon sequestration. Science 310, 1944-1947.

Jones, H.G., 1986. Plants and Microclimate. Cambridge University Press, Oxford, GB.

Kline, K.L., Coleman, M.D., 2010. Woody energy crops in the southeastern United States: two centuries of practitioner experience. Biomass Bioenerg. 34, 1655-1666.

Lorentz, K.A., Minogue, P.J., 2015. Potential invasiveness for Eucalyptus species in Florida. Invasive Plant Sci. Manage. 8, 90-97.

Lu, P., Urban, L., Zhao, P., 2004. Granier's thermal dissipation probe (TDP) method for measuring sap flow in trees: theory and practice. Acta Bot. Sin. 46, 631-646.

Martin, T.A., Jokela, E.J., 2004. Developmental patterns and nutrition impact radiation use efficiency components in southern pine stands. Ecol. Appl. 14, 1839-1854.

Meinzer, F.C., 2002. Co-ordination of vapour and liquid phase water transport properties in plants. Plant, Cell Environ. 25, 265-274.

Meinzer, F.C., Hinckley, T.M., Ceulemans, R., 1997. Apparent responses of stomata to transpiration and humidity in a hybrid poplar canopy. Plant, Cell Environ. 20, $1301-1308$.

Moreaux, V., O'Grady, A.P., Nguyen-The, N., Loustau, D., 2012. Water use of young maritime pine and Eucalyptus stands in response to climate drying in southwestern France. Plant Ecol. Divers.

Morris, J.D., Collopy, J.J., 1999. Water use and salt accumulation by Eucalyptus camaldulensis and Casuarina cunninghamiana on a site with shallow saline groundwater. Agric. Water Manag. 39, 205-227.

Myers, B.J., Theiveyanathan, S., O'Brien, N.D., Bond, W.J., 1996. Growth and water use of Eucalyptus grandis and Pinus radiata plantations irrigated with effluent. Tree Physiol. 16, 211-219.

O’Grady, A.P., Eamus, D., Hutley, L.B., 1999. Transpiration increases during the dry season: patterns of tree water use in eucalypt open-forests of northern Australia. Tree Physiol. 19, 591-597.

Oishi, A.C., Oren, R., Stoy, P.C., 2008. Estimating components of forest evapotranspiration: a footprint approach for scaling sap flux measurements. Agric. For. Meteorol. 148, 1719-1732.

Oren, R., Phillips, N., Ewers, B.E., Pataki, D.E., Megonigal, J.P., 1999. Sap-flux-scaled transpiration responses to light, vapor pressure deficit, and leaf area reduction in a flooded Taxodium distichum forest. Tree Physiol. 19, 337-347.

Otto, M.S.G., Hubbard, R.M., Binkley, D., Stape, J.L., 2014. Dominant clonal Eucalyptus grandis $\times$ urophylla trees use water more efficiently. For. Ecol. Manage. 328, 117-121.

Phillips, N., Oren, R., Zimmermann, R., 1996. Radial patterns of xylem sap flow in non-, diffuse- and ring-porous tree species. Plant, Cell Environ. 19, 983-990.

Phillips, N.G., Lewis, J.D., Logan, B.A., Tissue, D.T., 2010. Inter- and intra-specific variation in nocturnal water transport in Eucalyptus. Tree Physiol. 30, 586-596.

Roberts, J., 1977. The use of tree-cutting techniques in the study of the water relations of mature Pinus sylvestris L.: I. The technique and survey of the results. J. Exp. Bot. 28, 751-767.

Rubilar, R., Hubbard, R., Yañez, M., Medina, A., Valenzuela, H., 2017. Quantifying differences in thermal dissipation probe calibrations for Eucalyptus globulus species and E. nitens x globulus hybrid. Trees Struct. Funct. http://dx.doi.org/ 10.1007/s00468-017-1545-3.

Rutter, A.J., 1968. Water consumption by forests. In: Kozlowski, T.T. (Ed.), Water Deficits and Plant Growth 2. Academic Press, London and New York, pp. 23-84.

Sampson, D.A., Albaugh, T.J., Johnsen, K.H., Allen, H.L., Zarnoch, S.J., 2003. Monthly leaf area index estimates from point-in-time measurements and needle phenology for Pinus taeda. Can. J. For. Res. 33, 2477-2490.

Samuelson, L.J., Farris, M.G., Stokes, T.A., Coleman, M.D., 2008. Fertilization but not irrigation influences hydraulic traits in plantation-grown loblolly pine. For. Ecol. Manage. 255, 3331-3339.

Samuelson, L.J., Stokes, T.A., 2006. Transpiration and canopy stomatal conductance of 5-year-old loblolly pine in response to intensive management. For. Sci. 52, 313-323.

Schultz, R.P. (Ed.), 1997. Loblolly Pine: The Ecology and Culture of Loblolly Pine (Pinus taeda L.), US Department of Agriculture, Washington, DC.

Scott, D.F., 2005. On the hydrology of industrial timber plantations. Hydrol. Process. 19, 4203-4206.

Soares, J.V., Almeida, A.C., 2001. Modeling the water balance and soil water fluxes in a fast growing Eucalyptus plantation in Brazil. J. Hydrol. 253, 130-147.

Stanturf, J.A., Vance, E.D., Fox, T.R., Kirst, M., 2013. Eucalyptus beyond its native range: Einvironmental issues in exotic bioenergy plantations. Int. J. For. Res.

Stape, J.L., Binkley, D., Ryan, M.G., Gomes, A., 2004. Water use, water limitation, and water use efficiency in a Eucalyptus plantation. Bosque 25, 35-41.

Steppe, K., De Pauw, D.J.W., Doody, T.M., Teskey, R.O., 2010. A comparison of sap flux density using thermal dissipation, heat pulse velocity and heat field deformation methods. Agric. For. Meteorol. 150, 1046-1056.

Sun, G., Noormets, A., Gavazzi, M.J., et al., 2010. Energy and water balance of two contrasting loblolly pine plantations on the lower coastal plain of North Carolina, USA. For. Ecol. Manage. 259, 1299-1310. 
Sun, H., Aubrey, D.P., Teskey, R.O., 2012. A simple calibration improved the accuracy of the thermal dissipation technique for sap flow measurements in juvenile trees of six species. Trees 26, 631-640.

Uddling, J., Teclaw, R.M., Pregitzer, K.S., Ellsworth, D.S., 2009. Leaf and canopy conductance in aspen and aspen-birch forests under free-air enrichment of carbon dioxide and ozone. Tree Physiol. 29, 1367-1380.

USDA Plant Hardiness Zone Map, 2012. Agricultural Research Service, U.S. Department of Agriculture. <http://planthardiness.ars.usda.gov>.

Vance, E., Loehle, C., Wigley, T., Weatherford, P., 2014. Scientific Basis for Sustainable Management of Eucalyptus and Populus as Short-Rotation Woody Crops in the U.S. Forests 5, 901.

Vose, J.M., Allen, H.L., 1988. Leaf area, stemwood growth, and nutrition relationships in loblolly pine. For. Sci. 34, 547-563.

Vose, J.M., Miniat, C.F., Sun, G., Caldwell, P.V., 2015. Potential implications for expansion of freeze-tolerant eucalyptus plantations on water resources in the Southern United States. For. Sci. 61, 509-521.

Wear, D.N., Dixon, E., Abt, R.C., Singh, N., 2015. Projecting potential adoption of genetically engineered freeze-tolerant Eucalyptus in the United States. For. Sci. 61, 466-480.
White, D., Beadle, C., Worledge, D., Honeysett, J., Cherry, M., 1998. The influence of drought on the relationship between leaf and conducting sapwood area in Eucalyptus globulus and Eucalyptus nitens. Trees 12, 406-414.

White, D., Battaglia, M., Bruce, J., Benyon, R., Beadle, C., McGrath, J., Kinal, J., Crombie, S., Doody, T., 2009. Water-use efficient plantations-separating the wood from the leaves: Forest \& Wood Products Australia Ltd Report. Forest \& Wood Products Australia, Canberra, Australia. PNC073-0708.

White, D.A., Beadle, C.L., Worledge, D., Honeysett, J.L., 2016. Wood production pe evapotranspiration was increased by irrigation in plantations of Eucalyptus globulus and E. nitens. New Forest. 47, 303-317.

Whitehead, D., 1998. Regulation of stomatal conductance and transpiration in forest canopies. Tree Physiol. 18, 633-644.

Whitehead, D., Beadle, C.L., 2004. Physiological regulation of productivity and water use in Eucalyptus: a review. For. Ecol. Manage. 193, 113-140.

Whitehead, D., Edwards, W.R.N., Jarvis, P.G., 1984. Conducting sapwood area, foliage area, and permeability in mature trees of Piceasitchensis and Pinuscontorta Can. J. For. Res. 14, 940-947.

Zarnoch, S.J., 2009. Testing Hypotheses for Differences Between Linear Regression Lines. USDA Forest Service, Southern Research Station SRS-17. 